\title{
Rolling Stock Manufacturers and New Rail Vehicles in Poland
}

\author{
Marek GRAFF ${ }^{1}$
}

\begin{abstract}
Summary
Ten rolling stock manufacturers were operating in Poland in 2020. These were both domestic enterprises (Pesa, Newag) as well as branches of foreign concerns (Siemens, Bombardier, Alstom, Stadler). A similar division can be deemed conventional since the aforementioned enterprises employ mostly Polish specialists or managers - and work with Polish subcontractors. On the other hand, Polish manufacturers use mainly imported components in the production process. The range of the currently manufactured rolling stock is quite wide - from multiple units to locomotives with electric and diesel drives, adapted to run on both standard and broad gauge tracks. Polish plants also manufacture underground train-sets, mostly for export. New rolling stock orders placed by operators are carried out with the support of EU funding programmes.
\end{abstract}

Keywords: rolling stock manufacturers, Poland, PKP

\section{Introduction}

After 1989, the overwhelming majority of the rolling stock in Poland was operated by virtually one operator - PKP. In most cases, it was manufactured fully or in part domestically or supplied by the CMEA countries ${ }^{2}$. The majority of electric locomotives handling most of the transportation work were, however, manufactured in Poland (EU07, ET21, ET22 and ET41 series), only slightly supplemented by import (EP05, ET40 and ET42), while diesel locomotives that were primarily intended for freight traffic (ST43 and ST44 series) were imported. Passenger traffic vehicles (SP45, SU46), just like shunting vehicles (SM42, SM31), were mostly manufactured by domestic factories. No lightweight diesel vehicles (rail motored cars, diesel MUs) intended for local passenger services were in use after written off of the SN61 series (by Ganz-MÁVAG, Hungary).

The rolling stock assets of the time corresponded to the structure of Poland's economy, which relied on heavy industry mainly for political reasons. Therefore, the goods transported by rail included mainly coal, metal ores (especially iron), steel, as well as steel or timber products. Passenger transport, especially express routes with obligatory reservations, was neglected. Indeed, locomotives for high-speed passenger trains were not manufactured in Poland before the turn of the 1980s and 1990s (EP09 series). These replaced the remaining EP05s built in the early 1960s and the slightly younger EP08s. Most locomotives owned by PKP were not modern, and first-world technology - such as pulsed start-up of traction motors - was at the stage of testing or prototyping (EM10 series). The electric multiple units operated by PKP were mainly the EN57 series, which had been manufactured for 30 years without significant changes. The import of modern technical solutions from western countries was hindered due to the lack of convertible currency and the reluctance of the authorities to take action. It should be added that, due to the poor development of individual motor transport and of the country's road network (especially motorways and expressways), railway was the primary means of transport, both for passenger and freight, until 1989.

The abandonment of the command-and-quota economic system in favour of the free market model in 1989 brought about the collapse of Poland's heavy industry and a decline in transport (especially on secondary routes). However, it also resulted in the opening of the Polish economy to the world. This created an opportunity to obtain new, previously unavailable technologies. Such a situation entailed a necessity to restructure PKP and expand (among others) the existing express routes (IC and EC trains) due to the growing demand resulting from the dynamic development of private business. The economic crisis of the

\footnotetext{
${ }^{1} \mathrm{PhD}$; Institute of Nuclear Chemistry and Technology, Warszawa; e-mail: marek.graff@infotransport.pl.

${ }^{2}$ Council for Mutual Economic Assistance - an economic organisation operating in the years 1949-1991 and associating the following countries: Albania, Bulgaria, Czechoslovakia, Cuba, Mongolia, Poland, Romania, Hungary, East Germany, Vietnam and the USSR.
} 
1990s and the rather symbolic availability of EEC (EU predecessor) aid funds turned out, however, to be an obstacle to PKP's restructuring. The renovation and modernisation of the infrastructure as well as the purchase of new rolling stock were kept to a minimum, eventually becoming limited to the scrapping of unnecessary rolling stock (freight diesel locomotives primarily) and the decommissioning of side routes (transport financing from the state budget was minimal at the time).

Poland's accession to the EU in May 2004 and the funding received from aid programmes for infrastructure (e.g. OPI\&E, CEF, etc.) made it possible to initiate the renovation and modernisation of the railway network [46] and to acquire up-to-date machinery, initially from domestic manufacturers (mainly PESA), and later also from western companies that had bought out failed state enterprises in Poland (e.g. Alstom - Konstal Chorzów; Adtranz/ Bombardier - Pafawag Wrocław) or had built new factories from scratch (Stadler, Siedlce) [19, 20]. Poland's rolling stock manufacturers (Pesa and Newag) were transformed, and Rolling Stock Repair Plants (ZNTK) in Bydgoszcz and Nowy Sącz, respectively, were modernised. In addition to manufacturing tasks, the plants also deal with rolling stock overhauls and modernisation. However, some former manufacturers had to cease their activity (Fablok Chrzanów), while others failed to cope with the new, free-market reality (ZNTK Poznań, Kolzam Racibórz). In contrast, entirely new companies manufacturing trams as their core (Modertrans Poznań, Protram Wrocław) or additional products were also established (Solaris). It should be added that plants manufacturing rolling stock prior to 1989 (Pafawag Wrocław and H. Cegielski Poznań) lost their position as the main producers in Poland (primarily in the field of locomotives and EMU), and Pafawag's acquisition in 1997 by Adtranz/ Bombardier resulted in changes in its production profile and a significant improvement in quality.

After restructuring, H. Cegielski Poznań limited its production to passenger carriages intended primarily for the domestic market. With time, the rolling stock manufactured by Newag has slowly become comparable to vehicles produced by the world-class manufacturers now present in Poland - Alstom, Bombardier, Siemens, and Stadler. The changes taking place in Poland's railroad activity are represented by the Pendolino units supplied by Alstom to PKP IC between 2014 and 2015, together with other vehicles intended for use in handling long-haul traffic - Flirt and Dart units manufactured by the consortium of Stadler and Newag, and Pesa, respectively. Western concerns offer not only a wide range of vehicles, but also railway instrumentation and control (I\&C) equipment used in traffic safety systems (Bombardier, Siemens).
New trends among domestic manufacturers emerged after 1989 - vehicles are also exported (Germany, Italy, Czech Republic, Lithuania, and Ukraine, etc.), which was very rare previously (e.g. 201E locomotives for Moroccan Railways) [77], and vehicle import from the East virtually finished. Although Polish operators still use locomotives manufactured in the former USSR countries, these are modernised units (ST48, ST40s, and ST44-12xx series) or ones kept on in reserve (ET42 series). Furthermore, their numbers have dwindled (e.g. 1113 ST44 units plus 68 units for LHS were purchased; there are now fewer than 100 vehicles for 1435 track gauge use). The age of the aforementioned vehicles (30-40 years) is not without significance. Another new trend observed on Polish railways is the use of multi-voltage locomotives (virtually unused for passenger and freight trains prior to 1989) as a manifestation of the liberalisation of transportation between EU Member States.

The manufacturing of passenger and freight cars is an important issue. Whereas in the field of passenger carriage manufacturing after 1989, apart from the reduction of the number of units ordered by operators, the manufacturer has remained the same (a subsidiary of H. Cegielski Poznań) - Fabryka Pojazdów Szynowych (FPS-Railroad Vehicle Factory), the quality of the manufactured passenger carriages has improved. This greater focus on quality aims not only to meet new standards and regulations but also to satisfy the requirements of foreign railway operators from Germany, Czech Republic, Slovakia, Austria, and Hungary. Unfortunately, PKP IC, the operator managing long-distance routes, has concentrated rather on modernising the already existing rail car fleet instead of purchasing brand new rolling stock. Similar actions, caused by, among others, the lower costs of modernisation, will not be possible in the long term because the adoption of new technical requirements for passenger carriages will not always be feasible in the case of older rolling stock, manufactured e.g. 30 years ago. It should be added that nowadays it is standard to install $\mathrm{A} / \mathrm{C}$, closed-circuit monitoring, waste holding tanks, and electrical sockets by each passenger seat in the carriages. This all contributes to the fact that the travel standard has improved and the travel speed increased. The programmes of modernisation and purchase of new cars are being implemented with the use of EU funds. No cars for eastern passenger operators are currently manufactured, except for individual orders (e.g. prior to 1989, H. Cegielski produced many 1-WM gauge cars for SZD, based on provided documents).

Prior to 1989 , freight cars were manufactured in Poland in large numbers, both for the domestic market and for export. The following plants were the leading manufacturers (in terms of volumes): Zastal 
Zielona Góra, Pafawag Wrocław, the Wagon Factory in Świdnica, the Wagon Factory in Ostrów Wielkopolski, Marcel Nowotko Steelworks in Ostrowiec Świętokrzyski and more. Soviet Railways (SZD) as well as operators in Czechoslovakia, Hungary and Arab countries (Iraq, Syria and others) were the major purchasers [78]. In the post-1989 era, a significant decline in freight transport, resulting from the political transformation, as well as a slowdown in the export of freight cars to eastern operators led to the bankruptcy of several Polish manufacturers. Since freight transport is profitable, applying for EU aid funds is not necessary. At present, similar cars are manufactured by: Wagony Świdnica (owned by Greenbier from the USA), Europejskie Konsorcjum Kolejowe WAGON in Ostrów Wielkopolski, and Tabor Dębica. Companies operating in the field of manufacturing rail vehicles in Poland are listed in Table 1.

\section{Characteristics of rolling stock manufacturers in Poland}

This chapter provides background information on rolling stock orders for Polish operators and contracts implemented by rolling stock manufacturers in Poland (locomotives, multiple units, and underground, excluding trams) over the last few years. A detailed description of the rolling stock manufacturer situation in Poland after 1989 and orders received before 2015 are included in [21].

Rolling stock manufacturers in Poland

\begin{tabular}{|c|c|c|c|c|}
\hline Manufacturer & Origin & Manufacturing activity profile & $\begin{array}{c}\text { New vehicles and equip- } \\
\text { ment supplied to Polish } \\
\text { operators after } 1989 .\end{array}$ & Notes \\
\hline Alstom Transport & France & $\begin{array}{l}\text { locomotives, passenger cars, mul- } \\
\text { tiple units, underground, trams, } \\
\text { high-speed trains, automatic train } \\
\text { protection systems }\end{array}$ & $\begin{array}{l}\text { high-speed trains } \\
\text { underground, trams }\end{array}$ & global concern \\
\hline $\begin{array}{l}\text { Bombardier Trans- } \\
\text { portation }\end{array}$ & $\begin{array}{l}\text { Canada }+ \text { Ger- } \\
\text { many }\end{array}$ & $\begin{array}{l}\text { locomotives, passenger cars, mul- } \\
\text { tiple units, underground, trams, } \\
\text { high-speed trains, railway I\&C } \\
\text { equipment }\end{array}$ & $\begin{array}{l}\text { locomotives, trams, pas- } \\
\text { senger carriages, railway } \\
\text { I\&C equipment }\end{array}$ & $\begin{array}{l}\text { global concern, acquired by } \\
\text { Alstom in } 2020\end{array}$ \\
\hline $\begin{array}{l}\text { Europejskie Kon- } \\
\text { sorcjum Kolejowe } \\
\text { WAGON }\end{array}$ & Poland & freight wagons & freight wagons & $\begin{array}{l}\text { transformed wagons } \\
\text { Wielkopolski }\end{array}$ \\
\hline Greenbrier & USA & freight wagons & freight wagons & global concern \\
\hline H. Cegielski FPS & Poland & passenger cars & passenger carriages & $\begin{array}{l}\text { transformed H. Cegielski } \\
\text { Poznań }\end{array}$ \\
\hline Newag & Poland & locomotives, multiple units, trams & $\begin{array}{l}\text { locomotives, multiple } \\
\text { units, trams }\end{array}$ & $\begin{array}{l}\text { transformed ZNTK Nowy } \\
\text { Sącz }\end{array}$ \\
\hline Pesa & Poland & $\begin{array}{l}\text { locomotives, multiple units, pas- } \\
\text { senger cars, trams }\end{array}$ & $\begin{array}{l}\text { locomotives, multiple } \\
\text { units passenger carriages, } \\
\text { trams }\end{array}$ & $\begin{array}{l}\text { transformed ZNTK Byd- } \\
\text { goszcz and ZNTK Mińsk } \\
\text { Mazowiecki }\end{array}$ \\
\hline Siemens Mobility & Germany & $\begin{array}{l}\text { locomotives, passenger cars, mul- } \\
\text { tiple units, underground, trams, } \\
\text { high-speed trains, railway I\&C } \\
\text { equipment }\end{array}$ & $\begin{array}{l}\text { locomotives, under- } \\
\text { ground, trams, } \\
\text { railway I\&C equipment }\end{array}$ & global concern \\
\hline $\begin{array}{l}\text { Škoda Transporta- } \\
\text { tion }\end{array}$ & Czech Republic & $\begin{array}{l}\text { locomotives, multiple units, under- } \\
\text { ground, trams }\end{array}$ & underground, trams & international concern \\
\hline Stadler & Switzerland & $\begin{array}{l}\text { locomotives, passenger cars, mul- } \\
\text { tiple units, underground, trams, } \\
\text { high-speed trains }\end{array}$ & multiple units, trams & international concern \\
\hline Tabor Dębica & Poland & freight wagons & freight wagons & $\begin{array}{l}\text { some of the production } \\
\text { output is exported }\end{array}$ \\
\hline
\end{tabular}

[Author's own study]. 


\subsection{Alstom}

Alstom is a global concern from France and manufactures rail vehicles of virtually every type (locomotives, trams, high-speed trains, underground, etc.) as well as railway I\&C equipment. The Alstom Polish branch has, among others, a plant in Chorzów (formerly Konstal), which is a highly-specialised division of the concern, dealing with underground train engineering and construction. It has, however, recently been implementing a contract for the construction of multimodal multiple units for the main passenger carrier in the Netherlands - NS (Dutch Nederlandse Spoorwegen) (Fig. 1).

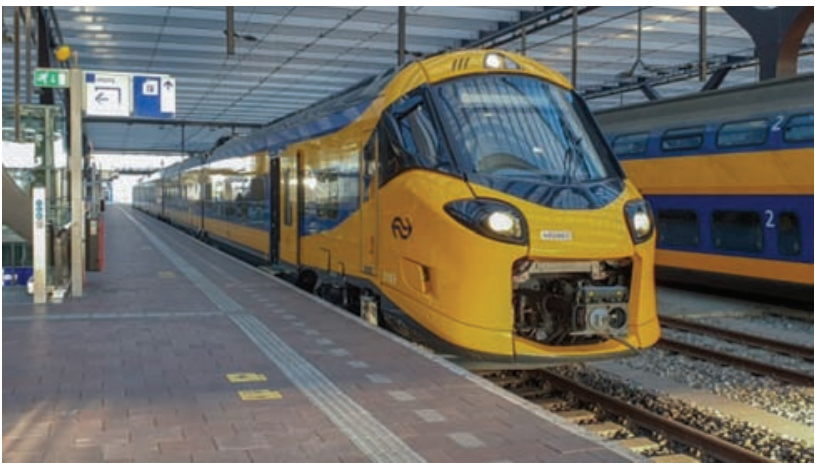

Fig. 1. ICNG EMU train set of the 3103 series (Alstom) operated by NS, Rotterdam Central Station [photo Mennov1996 / Wikimedia Commons]

Alstom has supplied, among others, the Metropolis trains for the Warsaw underground and EMU Pendolino for PKP IC, as well as Citadis trams for several Polish cities. The plant in Chorzów has manufactured underground rolling stock for export to underground rail systems in Amsterdam, Budapest, Riyadh, and Dubai. The Alstom plant in Chorzów was modernised and reorganised in the years 2016-2020, which cost EUR $100 \mathrm{~m}$. and - according to [32] - made it possible to:

- increase the output from 1 to 2 million manhours per year;

- enhance the production levels from 30 to 40 bodies per year;

- increase the production floor area from 65,000 sq. m to 90,000 sq. m;

and:

- construct on-site test tracks - 7 tangent tracks and 1 dynamic track (700 m long);

- establish a connection with the PLK network;

- obtain the certification of e.g. DIN 6701, which is required for approval to provide services to markets in Germany and the Netherlands;

- obtain the status of the largest centre of excellence for the construction of aluminium bodies, although steel bodies are also produced there;
- increase the share of aluminium bodies in the manufacturing volume from $2 \%$ to $23 \%$;

- double the share of equipment assembly;

- erect a multi-axial welding robot station;

- create new manufacturing posts for semi-automatic welding, automatic machining, and confined paint shops.

The plant in Chorzów is Alstom's leading facility. It independently implements both vehicle project initiatives and manufacturing process innovations. It should be added that, apart from the Alstom plant, aluminium bodies are also manufactured in the Stadler plant in Siedlce, with other vehicle manufacturers in Poland producing only steel bodies for both multiple units and locomotives. Industrial robots are in common use at the Alstom plant in Chorzów (Fig. 2).

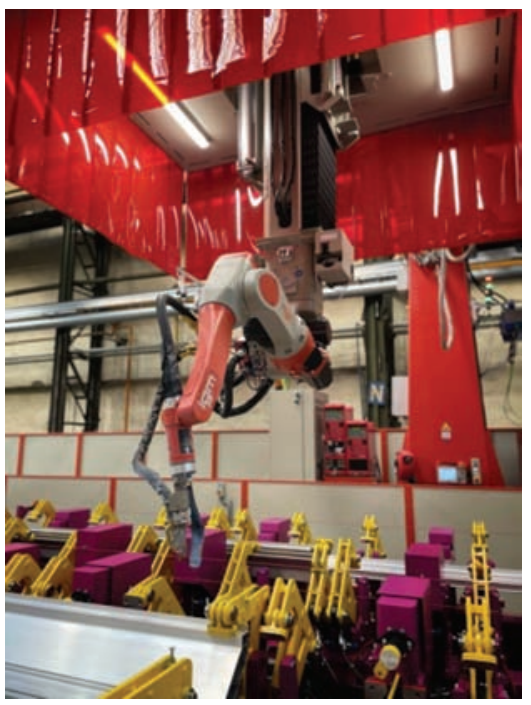

Fig. 2. Industrial robot at the Alstom Konstal plant in Chorzów [photo I. Burzyńska / Alstom]

\subsection{Alstom contracts}

In July 2013, Alstom was awarded a contract to construct a segment of the Riyadh underground system as a member of the FAST consortium, which was contracted to supply the rolling stock for lines 4,5 , and 6 - together with infrastructure equipment. A twelve-year contract with a preparatory period for the maintenance of lines 3, 4, 5 and 6 rolling stock was awarded to the FLOW consortium, with the participation of Ansaldo STS and Ferrovie Dello Stato Italiane (Italian Railways), among others. The contract was valued at EUR $2.5 \mathrm{bn}$, with the Alstom share at EUR $730 \mathrm{~m}$., which also covered rolling stock maintenance. The Saudi party set a condition that the minimum Saudi participation share index must be at least $45 \%$ and $55 \%$ for the local contribution in the field of supplies and services associated with underground oper- 
ation, including ground logistics support. The FLOW consortium committed itself to creating new jobs, for specialists, technicians, customer services personnel, security professionals, as well as administrative staff. The first Metropolis trains for Riyadh were manufactured in July 2016. Seats in three classes - first, family and single - separated with opaque glazing, were installed in the passenger section. In total, Alstom has supplied 69 two-carriage trains that will run on lines 4, 5, and 6. The first Alstom Metropolis train was shipped in March 2017. It was $36 \mathrm{~m}$ long, $2.71 \mathrm{~m}$ wide, and came with a capacity of 231 passengers. All of its axles are driven, which enables it to freely overcome slopes. Deliveries of Metropolis underground trains manufactured at the Alstom-Konstal plant in Chorzów were completed in mid-February 2019. The underground network was launched in November 2020 , although the entire network was commissioned in 2021.

The first underground train manufactured by Alstom for the Dubai transport authority was delivered in mid-November 2018 [27]. It was the first of 50 Metropolis train sets intended to run on Dubai's Red and Green underground lines. The trains were transported by land, from Chorzów to the German port of Bremerhaven, and then by sea, to the recipient. At the turn of 2018 and 2019, Alstom conducted static and dynamic tests at the depot. In 2016, the ExpoLink consortium, headed by Alstom partnering with ACCIONA and Gulermak, concluded a contract with RTA (Dubai Road and Transport Authority) to design and execute the extension of the Dubai Underground Red Line and modernise the systems of the existing line. The entire contract, also known as Route 2020, was valued at EUR $2.6 \mathrm{bn}$, and the commercial operation was scheduled for 2020 (start of the World Expo).

Alstom's scope of responsibility covered supplying underground rolling stock, an automated control, communication, and security system, an automatic toll inspection system, conducting track work and constructing screen doors at platforms, together with a 3-year warranty for the entire system. In addition, Alstom will improve the existing underground line through modernising the power supply, control systems, and communication and traction equipment. Metropolis train sets for Dubai are $85.5 \mathrm{~m}$ long and consist of 5 carriages, with a maximum capacity of up to 700 passengers, in three separate classes: Silver, Family, and Golden.

In early October 2017, Alstom concluded a contract for the supply of EMU Coradia Stream trainsets for Italy's and the Netherland's railway systems (FS and NS, respectively). These are units adapted to handling both regional traffic with a maximum speed of $160 \mathrm{~km} / \mathrm{h}$ and long-distance traffic, with a speed of $200 \mathrm{~km} / \mathrm{h}$ [7]. The manufacturer offered vehicles composed of a maximum of 10 cars with aluminium bodies, adapted to run on lines supplied with: $1.5 \mathrm{kV}$ DC, $3 \mathrm{kV} \mathrm{DC}, 15 \mathrm{kV} 16.7 \mathrm{~Hz}$ and $25 \mathrm{kV} 50 \mathrm{~Hz}$. In July 2016, NS ordered a total of 109 units to handle IC trains on the Amsterdam - Rotterdam - Breda and Hague - Eindhoven routes starting from 2021. These will be 5 -cars and 8 -cars trains, 49 and $30+30$ units respectively, with 256 and 417 seats. The operator ordered EMUs in a two-voltage version: $1.5 \mathrm{kV}$ DC and $25 \mathrm{kV} 50 \mathrm{~Hz}$, and a 3 -voltage (additionally $3 \mathrm{kV} \mathrm{DC}$, ICNG-B), which can operate within the domestic railway network and on a high-speed line (HSL Zuid), with the option of entering the Belgian railway network. One of the elements in the certification process is the testing in a climatic chamber at Rail Tec Arsenal in Vienna. EMUs have been equipped with the domestic ATB-EG, Belgian TBL1+ and ETCS security systems. The operational tests of the ICNG (InterCity Nieuwe Generatie) EMU designated as 3100 (5-cars), 3200 and 3300 (8-cars) series were commenced in June 2020 (unit 3108) [28]. ICNG deliveries were planned to start in January 2020, and commencing operation was planned for 2021, however, due to the COVID-19 pandemic, these dates were postponed. Similar units were ordered by FS during the Expo Ferroviaria trade fair in Milan in August 2016, under a contract valued at EUR $900 \mathrm{~m}$. for the supply of 150 EMUs. The implementation of the first part of the order, namely the supply of 47 units, commenced in early 2019. The FS version designated as ETR.103 was a single system (3 kV DC) and a 3- and 4-cars unit, with a maximum speed of $160 \mathrm{~km} / \mathrm{h}$, with 227 and 305 seats, respectively. The regions of Abruzzo (4 units) and Emilia Romagna (27 units) were the recipients.

In mid-December 2020, Alstom was awarded a contract for the design, construction, and maintenance of the third underground line in Toulouse, $27 \mathrm{~km}$ long, worth almost EUR $470 \mathrm{~m}$. Moreover, 28 train sets (with an option of extending to an additional 25 trains, totalling EUR $713 \mathrm{~m}$.) were ordered. The vehicle design was based on the Metropolis construction platform. The 21-station line will serve employees of the aviation sector (Toulouse is the location of the main EADS group centre, which manufactures civilian and military aircraft as part of the Airbus consortium). The transport capacity of the line is estimated at 5,000 people per hour in both directions, with an option to increase this number to 10,000 . The contract covers the provision of an efficient, proven Alstom system solution - namely, Metropolis trains, the Urbalis $^{\mathrm{TM}} 400$ CBTC system that enables automatic train running (without drivers), and Hesop ${ }^{\mathrm{TM}}$ power substations with energy recuperation. The scope of the contract also covers platform doors as well as the provision of a dynamic load signalling system and Appitrack - a rapid track laying system. The contract also 
provides for a 6-year maintenance period (extendable to 12 years). Some of the subassemblies will be manufactured in Toulouse (electrical equipment) and $\mathrm{Ta}$ bres (mechanical elements), and a total of $80 \%$ of the man-hours devoted to order processing will be completed in France, with 55\% in Occitanie. New jobs at Alstom's suppliers will be created in Toulouse, as well as throughout France for the purposes of the installation, infrastructure, and commissioning of individual systems. The Alstom Konstal S.A. plant in Chorzów will significantly contribute to the implementation of this project. As a Rolling Stock Integration Unit, the plant will be responsible for some of the engineering, the entire production, serial tests, commissioning and transport, as well as the in-warranty repairs of 28 trains of two cars.

\subsection{Bombardier}

In Poland, Bombardier operates plants in, among others, Wrocław (former Pafawag), which manufactures Traxx locomotive bodies, and ZWUS in Katowice, designing and producing traffic control devices. Selling the division responsible for the railway industry to Alstom enabled the company to focus on, among others, manufacturing jet aircraft for business clients. Alstom's acquisition of Bombardier Transportation assets will allow the French concern to advance to the second place in the world (after the Chinese CRRC) in terms of rolling stock and general railway manufacturing. Up until the 1990s, Pafawag Wrocław was the main manufacturer of electric locomotives and EMUs for PKP. However, the economic transformation after 1989 (decline in PKP orders) and the lack of capital to initiate the production of modern rolling stock resulted in the need to find a foreign entity (Adtranz in 1997, acquired by Bombardier in 2001) to enable the production output to be maintained. Bombardier's showcase products are currently electric and diesel Traxx locomotives used by Polish operator both in passenger and freight transport, domestically and internationally.

Traxx locomotive bodies are manufactured by Bombardier in their own plant in Wrocław, with 2,400 units already built. The locomotives are transported by road to a plant in Kassel, Germany, where their final assembly takes place. The Bombardier (now Alstom) plant in Wrocław uses industrial robots, among others, to weld metal (Fig. 3).

One of the latest solutions used by the manufacturer is an optional feature called the 'last mile. It eliminates the need to use an additional diesel locomotive on non-electrified railway network sections (e.g. industrial or port sidings, etc.). The feature involved equipping a locomotive with a low-power diesel engine and a fuel tank. The Traxx platforms, i.e. multi-system electric locomotives or their diesel version, have been in production for 18 years and their design enables vehicles to be tailored to the individual demands of a given operator, e.g. by installing domestic traffic safety systems.

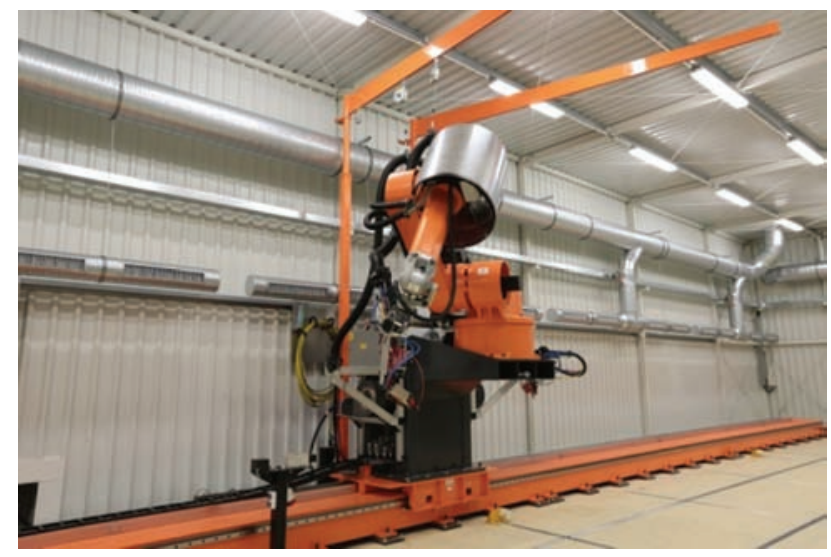

Fig. 3. Industrial robot for laser welding at the Bombardier plant in Wrocław [photo M. Kaczanowski / Bombardier, 07.06.2017]

Bombardier Transportation is a division of the concern that employs 40,700 people (with its headquarters in Berlin) and exports its own products, such as rolling stock, railway traffic control systems, comprehensive transport systems, e-mobility technologies, and maintenance services to over 60 countries (Fig. 4). The Polish branch comprises plants in Katowice, Łódź, Warsaw, and Wrocław, and employs almost 2,800 people. Altogether, Bombardier, with its seat in the Canadian city of Montreal, manages manufacturing and engineering plants in 28 countries, and operates in such sectors as transport, business and aircraft manufacture and design, aviation structures, and engineering services. Bombardier shares are traded on the Toronto Stock Exchange (BBD). In the fiscal year that ended on 31 December 2018, Bombardier reported a revenue of USD $16.2 \mathrm{bn}$. The concern employs 69,500 people within 4 fields of activity.

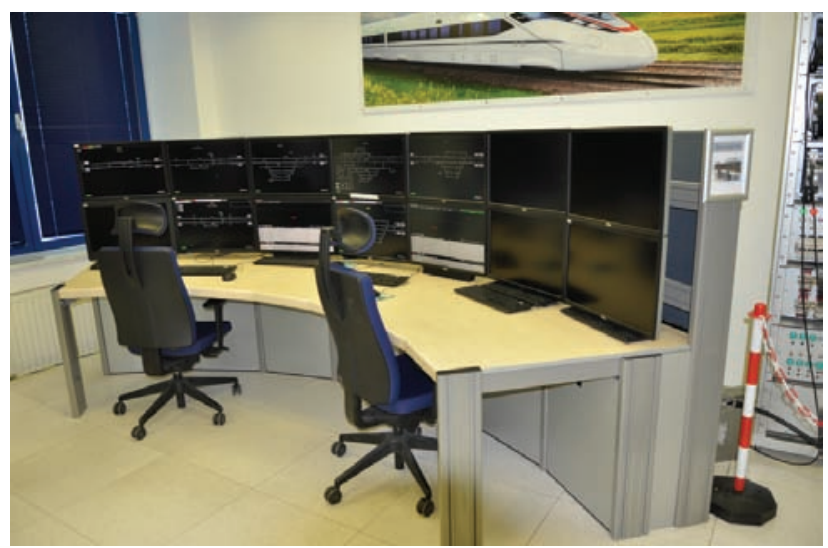

Fig. 4. Traffic safety system test stand at the Bombardier ZWUS plant in Katowice [photo M. Graff, 30.05.2017] 
At the end of February 2019, the Canadian-German rolling stock manufacturer Bombardier and the French leasing company Akiem signed an agreement regarding the order of 20 Traxx DC3 locomotives for the Polish market, which was part of an overall plan involving the supply of 33 Traxx AC, DC, and MS locomotives that was to be completed in the period of 2019-2021. Akiem representatives also stated that, by 2020 , their own rolling stock assets would consist of a minimum of 180 locomotives, of which 55 were intended for operation within the Polish railway network and for use in dealing with cross-border traffic. For rolling stock maintenance, Akiem, employs a network of specialised service centres (MGW Service). As the owner of 440 locomotives and serving approximately 50 customers that operate in the field of freight or passenger transport in most European countries, the Akiem Group generates revenues of EUR $140 \mathrm{~m}$. The company belongs to Transport et Logistique Partenaires and DWS, and employs about 150 people in France, Italy, Germany, Sweden, and Poland in its leasing and maintenance departments. For operators which use Traxx locomotives, is offered the supply of spare parts, maintenance, and servicing. Akiem has decided to open an office in Warsaw in order to support the development of both Akiem and MGW Service in Central Europe.

\subsection{Alstom and Bombardier Transportation merger}

At the end of July 2020, the European Commission approved Alstom's plans to acquire the Bombardier Transportation concern. This meant the formation of the second largest railway sector manufacturer in the world, after the Chinese giant - CRRC $[8,10,15]$. The European Commission approved the acquisition (subject to numerous conditions), including the sale of shares in:

- Bombardier Transportation: high-speed V300 Zefiro trains, currently operated by FS;

- Alstom: the Coradia Polyvalent unit family, manufactured in the electric, diesel or electric, and diesel hybrid versions.

According to the EC, including M. Vestager, EC Executive Vice President and Commissioner for Competition, the merger of both companies is beneficial since a new, strong concern will be formed on one side, with the activities of other entities, e.g. Siemens or CAF, both of whom manufacture similar vehicles (locomotives, MUs, high-speed trains, railway I\&C, etc.) not being endangered. In other words, there will be no situation where one concern monopolises the market and adversely impacts the potential implementation of future innovations and the purchase prices of new vehicles. In February 2020, Alstom announced a plan to acquire $100 \%$ of Bombardier Transportation's shares, offering from EUR 5.8 to $6.2 \mathrm{bn}$. According to the agreement with Bombardier Inc. and CDPQ (Caisse de Dépôt et Placement $d u$ Québec), which at the time held 32.5\% of all Bombardier Transportation shares, CDPQ will become the largest shareholder in the Alstom concern (17.5\% of shares). Furthermore, CDPQ will invest approx. USD 2 bn in Alstom, plus an additional EUR $700 \mathrm{~m}$. Moreover, the French industrial group Bouygues will become an Alstom shareholder (10\% of the stocks). EC concerns regarding the merger of both companies were associated with several aspects of the original purchase proposed by Alstom, including:

- high-speed trains, in the field of which the new entity would become an undisputed market leader with a significant standing, although it should be noted that similar rolling stock is manufactured by Siemens or CAF, hence the reservation may only concern the market position;

- classic rolling stock (MUs and locomotives), in the case of which the new entity would gain a strong position, in France and Germany in particular;

- railway I\&C - Alstom and Bombardier currently have a significant share in the aforementioned supply segment, therefore difficulties will arise for other vendors to participate in tendering procedures that involve ensuring ETCS compatibility with older (legacy) traffic safety systems. This situation could potentially lead to a reduction in the role of smaller companies to being sub-suppliers;

- urban signalling systems (trams and underground): The EC found that the proposed transaction would not raise concerns in terms of competition in the field of signalling systems for urban rail vehicles, although it should be added that Bombardier had not previously expressed interest in this segment.

To alleviate the EC's concerns regarding the impact of Bombardier Transportation's acquisition on the European railway market, Alstom has committed to several key initiatives, including [4]:

- Bombardier Transportation's contribution to the V300 Zefiro high-speed train and the transfer of an intellectual property licence to Hitachi in the case of the train developed jointly by Hitachi and Bombardier to be offered in the rolling stock tender for the British HS2;

- production lines, together with Coradia MU patent rights (electric, including multi-system and diesel-electric), plus the plant in Reichshoffen in France that belongs to Alstom;

- production lines, together with Talent $3 \mathrm{MU}$ patent rights and the plant in Hennigsdorf, Germany that belongs to Bombardier; 
- access to specified interfaces and certain devices that are part of onboard signalling systems and train control management systems (TCMS) developed by Bombardier.

According to Alstom, the acquisition of shares in the Bombardier concern was to take place in mid2021 - subject to approval by the relevant regulatory authorities, including the European Commission, with each of the authorities having its own time frame. Originally, the EC's decision was to be announced in mid-July, but was postponed to late July 2020. One of the EC's control instruments is the option to initiate a 4-month investigation in the case of serious doubts regarding suspected infringement of competition. A similar investigation by the European Commission prevented the merger between Alstom and Siemens in February 2019. This came about because the German industrial union IG Metall called upon the German government to investigate the deal. As a result, in February 2019, the Commission blocked the previously proposed merger between Siemens Mobility and Alstom, saying that the companies did not come up with sufficient remedies to address EC concerns regarding competition in the signalling system and high-speed rolling stock markets.

However, there are several factors that differ between the two transactions. Above all, the AlstomBombardier merger is a smaller-scale transaction than the proposed one with Siemens, which some analysts believe could have resulted in a $70 \%$ share of a single entity in the rolling stock or automation market. Moreover, the transaction is technically an acquisition - not a merger, based on more complementary than competitive elements - Bombardier is a smaller player, e.g. in the case of high-speed trains, and had formed consortia in this field with other companies, like Hitachi in Italy and Siemens in Germany. The decision of the Commission faced a critical response, of e.g. SCI Verkehr, which raised an argument of concern for jobs in the plants of both Bombardier and Alstom in Germany and France, as one of the objectives of the Bombardier takeover. Furthermore, SCI Verkehr claimed that, currently, ten of the biggest global railway equipment manufacturers already supply $77 \%$ of the world's new rolling stock. The leaders are:

1. CRRC, a holding from China with virtually a monopoly over the Chinese market, although the entity often forms consortia with western entities for the purpose of tendering procedures in China;

2. Alstom - after acquiring Bombardier Transportation;
3. Transmashholding (TMH), Russia, a leader in the post-Soviet area (rolling stock on $1,520 \mathrm{~mm}$ gauge), although the company also wins other contracts (e.g. the supply of 1,300 passenger carriages for Egyptian railways) [30];

4. Siemens Mobility, an engineering company operating in the rail sector. It is present in almost all continents, and is responsible for, among others, the recent revival of urban rail transport in the USA. The enterprise has increased its revenue and profits in recent years;

5. Trinity Industries, a US holding operating in the transportation, power and construction industries; the company has recently supplied significant numbers of freight wagons;

6. Stadler, Switzerland - which is successful owing to, among others, the manufacture of Flirt sets that are used in Europe and North America;

7. Hitachi Rail, an engineering concern from Japan, also present in Europe (recent contracts for British and Italian railways);

8. Greenbrier Companies, a carriage manufacturer from the USA, which sells its products mainly in Europe and South America ${ }^{3}$;

9. Wabtec from the USA, after acquiring GE Transportation.

It is estimated that the railway market consolidation index has increased relative to 2017, with the 10 largest manufacturing increasing their share in the global market from $73 \%$ to $77 \%$ in 2019 . A formal conclusion of the purchase and sale agreement covering the acquisition of Bombardier Transportation from Bombardier Inc. and CDPQ was announced by Alstom in mid-September 2020 [5]. The transaction was closed in Q1 2021, after the regulator's approval. A price range reduction by EUR $300 \mathrm{~m}$. to approx. EUR 5.5-5.9 bn was achieved, excluding all further downward adjustments associated with the net cash protection mechanism. According to Alstom's top management, the acquisition could amount to EUR $5.3 \mathrm{bn}$, compared to the EUR 5.8 to 6.2 bn range announced on 17 February 2020. The financing structure remained unchanged, and CDPQ will become Alstom's largest stakeholder, with a share capital of $18 \%$ and voting rights. It is expected that the transaction will provide a double-digit increase in profit per share in the second year after closure and enable the maintenance of Alstom's Baa 2 credit rating.

The price was reduced from a range of EUR 5.8 bn to 6.2 bn agreed in February 2020 due to the opera-

\footnotetext{
${ }^{3}$ Greenbrier Companies acquired the former plant - Fabryka Wagonów (Carriage Factory) Świdnica and is currently producing freight carriages for both Polish and foreign markets.
} 
tional performance of Bombardier Transportation, the COVID-19 pandemic, and broader market conditions, excluding any further downward adjustments associated with the net cash protection mechanism [3]. Currently, Alstom is expecting this figure to further decline to EUR $5.3 \mathrm{bn}$, based on the estimated potential post-closure adjustment and a commitment related to this mechanism. Bombardier Transportation reported an adjusted EBIT loss (operating profit before taxes and interest) of USD $383 \mathrm{~m}$. for Q2 2020, which was announced on 6 August, after recording revenue of USD $1.5 \mathrm{bn}$ for this period. Adjusted EBITDA (operating profit before depreciation of fixed tangible assets and amortisation of intangible and legal assets) amounted to USD $-350 \mathrm{~m}$. for the quarter, reflecting the lower production output that came about because the operations in key locations in Europe and North America were suspended due to the COVID-19 pandemic.

Alstom confirmed its objectives of achieving operating cost synergy of EUR $400 \mathrm{~m}$. per year from the $4^{\text {th }}$ to the $5^{\text {th }}$ year after the acquisition and after restoring Bombardier Transportation's margin to a standard level in the average term. According to Éric Martel, Bombardier's CEO, the revenue from the aforementioned transactions will enable it to commence the transformation of the group's capital structure and focus on its financial balance by repaying its debts, and allow it to fully utilise the potential of in-house employees and maintain its leading position in the field of manufacturing business jets.

After receiving information about Bombardier's financial results, including the adjusted EBIT loss of USD $383 \mathrm{~m}$. in Q2 2020, Alstom modified the purchase price of the Canadian company [6]. Bombardier described the EBIT loss as well below expectations, but one that reflected the additional burden of USD $435 \mathrm{~m}$., primarily resulting from increasing engineering, certification and modernisation costs associated with numerous projects at a late stage, mainly in the United Kingdom and Germany. Alstom's management still believes in strong, strategic rationale behind the acquisition of Bombardier Transportation, and assumes that its profitability and commercial results will be restored. However, the announced Q2 data indicated unexpected and adverse events regarding Bombardier Transportation's condition. The company is currently facing challenges, especially relative to information available prior to the announcement from February 2020, when the acquisition was planned. According to Bombardier's management, the prospects for transport remained positive and the company reported an order portfolio of USD $33.7 \mathrm{bn}$. In addition, with plants returning to standard operation, it was assumed that production would accelerate in the second half of 2020 and reach the 2019 level in Q4.
It was also expected that the delays in engineering and manufacturing associated with COVID-19 would be eliminated in 2021. Moreover, a newly appointed team was authorised to conduct deep changes in company practices during the first quarter of 2020 . The team was to assess both the management processes (organisation) and vehicle engineering, and to answer questions regarding the factors generating excessive costs. This would enable appropriate corrective measures to be undertaken. It should be noted that Bombardier Transportation has recently reported delays in the supply of Talent 2 EMUs for Abellio Rail in Baden Württemberg and Talent 3 EMUs for Southwest German Transport (Sweg), as well as Aventra EMUs for the Crossrail line in London, London Overground and Greater Anglia, and the South Western franchise. The loss of USD $350 \mathrm{~m}$. was associated with the delays in fulfilling project deadlines and contributed to an adjusted EBIT loss of USD $230 \mathrm{~m}$. in Q4 2019.

Alstom itself reported a $27 \%$ decline in the sales in Q1 (from 01.04 to 30.06.2020) of the financial year 2020-2021 due to the Coronavirus pandemic [9]. During this period, the volume of sales dropped from EUR $2.05 \mathrm{bn}$, to $1.5 \mathrm{bn}$, although the volume of orders increased by $2 \%$, from EUR 1.62 bn in the same period in 2019-2020, to EUR $1.65 \mathrm{bn}$. The accounting relation relative to current accounts in this period was 1.1, and the order portfolio remained at a level of EUR $41.2 \mathrm{bn}$ as of 30.06 .2020 . Despite the latter, the company maintains a positive approach and expects that its business activity will be back to normal relatively soon after the pandemic. According to Henri Poupart-Lafarge, the company's CEO, Alstom's operating activity was maintained thanks to remote work, but there was a certain negative impact on the operation of the company's plants and supply chain. Despite the crisis, Alstom's commercial activity remained stable. Orders continued to come uninterruptedly from operators in Africa, the Middle East, and Central Asia (rolling stock), Taiwan (Taipei underground), Mexico, China, USA, Greece (mixed supplies), Europe and the USA (signalling systems). The decline in sales was caused mainly by the slowdown during the COVID-19 crisis shutdown, especially in terms of rolling stock manufacturing. Services were less affected by reduced train traffic, while signalling systems suffered from installation rate slowdown. As of mid-July 2020, Alstom's operations returned to normal and the supply chain was resumed in line with the manufacturing output. In late June 2020, Alstom also announced the acquisition of Ibre, a manufacturer of cast iron and steel brake discs, which is a significant expansion of the Alstom in Motion (AiM) Strategic Plan.

Ibre employs around 30 people in its headquarters in Sens, Bourgogne Franche-Comté, and reported a turnover of approximately EUR $10 \mathrm{~m}$. in 2019. According to 
Alstom's management, the continued COVID-19 crisis is likely to adversely impact the financial results in the 2020-2021 fiscal year, including the accepted order volume, net income, free cash flow, and sales volume, although it is currently impossible to accurately estimate the aforementioned factors. In the aftermath of the current crisis, Alstom expects a rapid rail market recovery, supported by a solid foundation and growing demand for sustainable mobility. Therefore, the objective of a $5 \%$ annual average growth rate in the period from 2019-2020 to 2022-2023 should be only slightly impacted by the temporary slowdown in the company's activities, and the 2022-2023 objectives of a 9\% adjusted EBITA margin and a change in the net income into free cash flow above $80 \%$ should be achievable. Alstom's management believes that, owing to the strong liquidity, the demonstrated operational capacity and profitability, as well as the rapid launch of the cost and cash containment plan, the company is prepared to survive the crisis and to take the opportunities in the thriving railway market - as well as to contribute to the transition to sustainable transport systems.

In late January 2021, Alstom completed the Bombardier Transportation acquisition process $[1,2]$. The combined group employs 75 thousand people in 70 countries, generates a revenue of approximately EUR 15.7 bn, has assets worth EUR 71.1 bn, boasts extensive research and development assets, and has manufactured a total of 150 thousand vehicles, which makes it the second largest entity in the world in terms of revenue. The holding is primarily present in Europe - France, Italy, and Spain, but also in India, South-East Asia, North Africa, and Brazil. The previous Bombardier Transportation was present in such markets as the United Kingdom, Germany, the Scandinavian countries, China, and North America (USA and Canada). In total, the merged concern has access to $75 \%$ of the original equipment manufacturer (OEM) market. The reference price set at EUR 5.5 bn falls within the lower part of the EUR 5.5-5.9 bn range announced in mid-September 2020. The total sales revenue was set at EUR $4.4 \mathrm{bn}$, thus less than the previous estimates, due to the unfavourable market conditions (Bombardier Transportation's negative net cash position at the end of December 2020 and other contractual adjustments), as well as Bombardier's doubts regarding certain provisions governing the takeover. Bombardier Inc. expects that the net inflows will amount to approximately USD $3.6 \mathrm{bn}$, including USD $600 \mathrm{~m}$. for Alstom shares, which will be redeemable as of late April 2021, and the obtained funds will be assigned to debt repayment. The acquisition of Bombardier's shares was financed by:

- the issue of preemptive rights to the amount of approximately EUR 2 bn, completed in early December 2020;
- part of the EUR 750 m. priority bond issue completed in mid-January 2021;

- increasing the reserve capital for CDPQ and Bombardier Inc. subsidiaries to the amount of EUR 2.6 bn and EUR 500 m., respectively.

Alstom has confirmed its objective of generating EUR $400 \mathrm{~m}$. of annual cost synergies by the $4^{\text {th }}$ or $5^{\text {th }}$ year and restoring Bombardier Transportation's margin to a standard level in the average term. Alstom intends to finalise the sale of some assets, following the requirements of the European Commission regarding acquisition approval. Alstom's North American HQ will be located in Montreal, Quebec, Canada, and will manage all regional operations and establish a research centre for engineering and design based on Quebec's strengths in terms of innovation and sustainable mobility. Both Alstom and Bombardier had their own manufacturing plants in Poland, but it should be noted that these are complementary - not competing - entities. For example:

- the Konstal plant in Chorzów is an Alstom division specialising in underground train manufacturing, although it also produces trams and, recently, EMUs of a maximum speed of $160-200 \mathrm{~km} / \mathrm{h}$ (order for NS and FS). In 2000, this plant supplied Metropolis trains for the underground rail system in Warsaw, and trams for the Katowice, Warsaw, and Gdańsk transit systems;

- the former Bombardier plant in Wrocław manufactures bodies for Traxx locomotives. These are also operated by Polish operators;

- the ZWUS Katowice plant manufactures I\&C hardware and software for rail communication systems;

- the trams that were supplied by Bombardier (MPK Kraków was a big client) were assembled using the carrier's own capacities and resources, without launching a new assembly line or opening a new plant.

It should be added that both companies also have other plants in Poland, which, however, operate outside the railway industry. Thus, as separate entities, there was no competition, but rather complementation. What is more, Bombardier has supplied numerous Traxx locomotives to Polish rail entities, while the Prima locomotives developed by Alstom are used in France and outside Europe rather than in Poland. The tram market case was similar. In Poland, although this market segment is dominated by Pesa, some contracts were awarded to Bombardier and Stadler, with Alstom virtually withdrawing from it after 2000. Moreover, Pesa and Newag dominate the Polish market of diesel and electric multiple units (due to, e.g. the price criterion being a key factor), although Stadler has recently been awarded an increased number of contracts. 


\subsection{H. Cegielski FPS}

H. Cegielski FPS (Railway Vehicle Factory), which is a separate section of the former $\mathrm{H}$. Cegielski concern (a company involved in marine engine manufacturing, among others), currently produces - or modernises - passenger cars for PKP IC. Until the beginning of the 1990s, the Poznan'-based manufacturer, however, produced electric and diesel passenger locomotives for PKP. Unlike Pafawag, the plant from Poznań has not been supported by foreign entities, therefore, the stated intentions to commence the production of MUs or trams have not yet been implemented. $\mathrm{H}$. Cegielski FPS conducts repairs and modernisations of diesel locomotives operated by Polish operators.

After completing a 3-year restructuring programme in March 2020, H. Cegielski FPS announced that [17]:

- plant sales increased 5.5 times, to a value of PLN $213 \mathrm{~m}$. in 2019;

- a net profit increase was reported for the second year in a row - PLN $2.7 \mathrm{~m}$. in 2019;

- EBIDTA (operating costs excluding depreciation) amounted to PLN $13 \mathrm{~m}$.;

- TSI (Technical Specifications for Interoperability) requirements were implemented in the manufactured passenger carriages;

- the order portfolio amounted to approx. PLN 1 bn;

- FPS put in place a new production, planning, and logistics organisation;

- adequate financing of implemented projects was ensured;

- co-financing from the National Centre for Research and Development for development projects to the amount of PLN $34.2 \mathrm{~m}$ was obtained;

- ERP (enterprise resource planning) was introduced in 2018. This is a recognised system for the effective management of resources.

H. Cegielski FPS sp. z o.o. is currently owned by the Polish Industrial Development Agency (PL: Agencja Rozwoju Przemysłu), and proper collaboration with banks and insurance companies makes it possible to secure contract liquidity. In late May 2019, PKP IC decided to modify the contract with $\mathrm{H}$. Cegielski FPS, which provided for the supply of 55 passenger cars. The contract was expanded to include an extra 26 units (total contract value of PLN 697.3 m.) [33]. The ordered cars are approved for traffic within the railway network of Poland, as well as the Czech Republic, Germany, Austria, Slovakia, and Hungary. The manufacturer selected DB Systemtechnik - a notified body (NoBO) to conduct the process of approval for operation, to verify the fulfilment of requirements for individual subsystems or interoperability constituents (e.g. compatibility with existing infrastructure), and to issue the required verification certificates (a car certification process is first implemented at the engineering and manufacturing stage, and covers the selection of proper subassemblies and materials, as well as appropriate technologies). Technical and operational tests of the carriages were conducted on an experimental track in Velim, Czech Republic, which provided the possibility of supplying the traction line with several types of voltage ( $3 \mathrm{kV} \mathrm{DC}, 15 \mathrm{kV} 16.7 \mathrm{~Hz}$, $25 \mathrm{kV} 50 \mathrm{~Hz}$ ). This enabled the study of, among others, the impact of a given voltage type on the carriage's electrical system. In mid-January 2020, the operator announced that static tests of the bodies were ongoing and crash tests had been completed. The carriage entry into service permit procedure changed in midJune 2020 and is now conducted under the supervision of the European Railway Agency and not the Polish Office of Rail Transport (PL: Urząd Transportu Kolejowego/UTK) [71].

According to the contract concluded in November 2017 with FPC, PKP IC completed the acceptance of modernised $2^{\text {nd }}$-class cars worth PLN $410 \mathrm{~m}$. [62]. The contract stipulated that the contractor conducted P5 repairs, along with modernisation and $\mathrm{P} 3$ repairs of $111 \mathrm{~A}$ cars (174A after modernisation). The P5 repair also involved the installation of 25AN bogies with significantly more advantageous travel properties, relative to older-type bogies (e.g. 4ANc). FPS completed the contract 5 months prior to the deadline, and the modernisation involved the installation of air-con, electric sockets, route displays, contained waste storage, 6-seat passenger compartments, cellular signal amplifiers, and devices providing wireless Internet. The new rolling stock started running in December 2018. PKP IC assigned the modernised carriages to run on the following routes:

- IC Bolko on the Szczecin - Lublin - Szczecin route,

- IC Gryf on the Szczecin - Olsztyn - Szczecin route,

- IC Drwęca and IC Jeziorak on the Olsztyn Poznań - Olsztyn route,

- IC Albatros on the Gdańsk - Szczecin - Gdańsk route,

- IC Żuławy on the Szczecin - Olsztyn - Szczecin route,

- IC Mewa on the Warsaw - Szczecin/Gorzów Wlkp. - Warsaw route,

- IC Mamry on the Wrocław - Białystok - Wrocław route,

- IC Sztygar and IC Morcinek on the Wrocław - Lublin - Wrocław route,

- IC Jagiełło on the Lublin - Kraków - Lublin route,

- IC Hetman on the Wrocław - Lublin/Hrubieszów - Wrocław route,

- IC Korfanty on the Wrocław - Katowice - Wrocław route, 
- IC Pomorzanin on the Gdynia - Wrocław - Gdynia route,

- IC Starzyński on the Warsaw - Terespol - Warsaw route,

- IC Zielonogórzanin on the Warsaw - Zielona Góra - Warsaw route;

and also in the near future:

- Szczecin - Trójmiasto (Tricity) - Olsztyn - Białystok,

- Wrocław/Zielona Góra - Poznań - Gdynia/Olsztyn - Białystok,

- Kraków/Lublin - Katowice - Wrocław - Zielona Góra - Szczecin - Świnoujście,

- Przemyśl - Lublin - Warsaw - Bydgoszcz - Gdynia/Piła - Kołobrzeg/Gorzów Wlkp.,

- Suwałki - Białystok/Lublin - Warsaw - Poznań Szczecin/Gorzów Wlkp./Zielona Góra.

The construction of 8 passenger carriages ordered by the Ministry of National Defence, which was commissioned in 2020, was an unusual order for FPS. At the end of 2018, H. Cegielski FPS was also the only contractor to place a bid in the tender for the modernisation of ten $1^{\text {st }}$-class carriages of the 145Ab type with managerial compartments, involving a conversion to restaurant cars [63], which includes the current P5 repair and later P3 repair, with a unit value of PLN $6.13 \mathrm{~m}$. and PLN 153.3 thousand, respectively, with a 36-month warranty. Because the budget allocated by the operator was lower than the price offered by the moderniser, PKP IC decided to accept FPS's terms (the tender decision date was postponed twice). One of the reasons behind the modernisation of the $145 \mathrm{Ab}$ cars was frame deformations and body fragment detachment in the Bautzen 89 carriages, manufactured by the East-German producer, VEB Waggonbau Bautzen. These faults practically determined that they had to be scrapped [29]. It should be added that DR acquired similar carriages in 1984 (DB designation $\mathrm{WRm}^{130}$ ). However, their operation ended a few years ago, probably for similar reasons to those in the case of the PKP carriages. PKP IC received the modernised restaurant cars in early November 2020 [57]. The moderniser installed 12 tables and 36 seats in the carriages.

In early December 2019, PKP IC concluded a contract with FPS, valued at PLN $90.3 \mathrm{~m}$. gross, for the updating of 13 SM42 diesel locomotives [18]. The entire undertaking was financed under the Operational Programme Infrastructure and Environment 20142020, under the following project titles:

1. Time for new connections - modernisation of carriages and locomotives for PKP Intercity S.A.

2. Accelerating comfortably - modernisation of carriages and purchasing locomotives for PKP Intercity S.A.
In the spring of 2018, the operator signed a contract with the Centre for EU Transport Projects (PL: CUPT) for the co-financing of the aforementioned project to the amount of PLN $653.8 \mathrm{~m}$., with a completion time of 24 months. According to the agreement, the SM42 series was to be rebuilt into two-unit vehicles that were capable of supplying the hauled passenger carriages with electricity. The locomotives were to obtain microprocessor controls, new diesel engines with lower fuel consumption and an overall better performance, and the driver cabins were to be fitted-out in accordance with the principles of best ergonomics.

\subsection{Newag}

Newag, which is the former ZNTK Nowy Sacz, was acquired and recapitalised by an investment fund in 2005. The flagship vehicles manufactured by Newag are the Impuls MUs (electric, diesel, hybrid) for Polish regional operators (Fig. 5), Griffin electric locomotives for passenger traffic, and Dragon electric locomotives for freight trains. Besides the $3 \mathrm{kV}$ DC version, Newag has also developed $15 \mathrm{kV} 16.7 \mathrm{~Hz}$ and $25 \mathrm{kV} 50 \mathrm{~Hz}$ options. Newag also exports to Italy (Impuls EMU, Vulcano DMU) and carries out repairs and modernisations of electric and diesel rolling stock - as well as of passenger cars owned by Polish operators. The entity forms consortia with other manufacturers (Siemens, Stadler) for the purpose of tendering procedures organised in Poland and abroad.

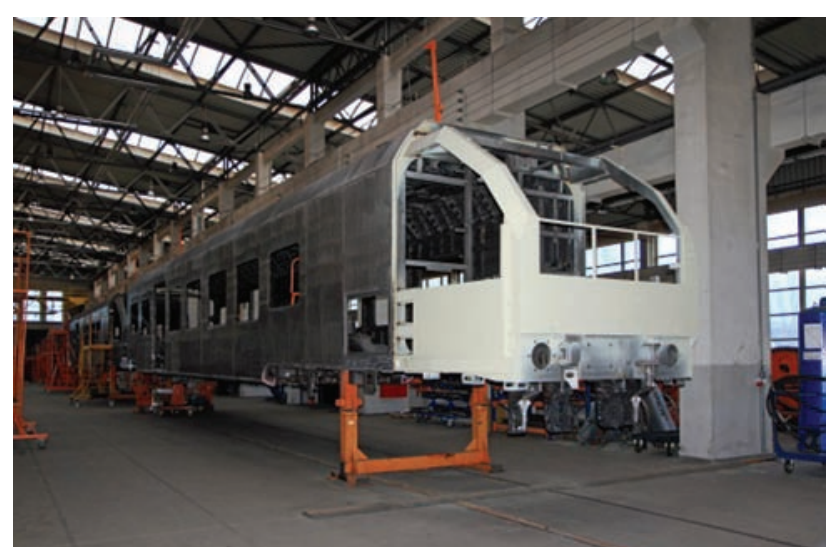

Fig. 5. Impuls MU body, Newag [photo M. Wojtaszek, 27.12.2016]

In late September 2020, the Nowy Sącz-based manufacturer published a financial statement for the first half of 2020 (with some data of a preliminary nature) $[11,12]:$

- achieved profit is 4 times higher relative to January - June 2019 - PLN $62.1 \mathrm{~m}$. and PLN $12.4 \mathrm{~m}$., respectively;

- difficulties associated with shipping Impuls 2 EMUs of the ETR322 series to the Italian operator 
FSE were reported - units will be handed-over in the first half of 2021 (planned for 2020);

- $4 \%$ higher sales revenues - i.e. PLN 569.3 m.;

- EBITDA ${ }^{4}$ value of PLN 111.9 m., which is $154 \%$ higher, resulting from a more favourable distribution of sales plans according to the producer;

- the dividend paid to shareholders is higher;

- total order portfolio value of PLN 2.4 bn;

- the hybrid unit presented at the Trako 2019 trade fair is a new type of vehicle, and the first orders for the unit have already been placed.

At the end of November 2020, Newag announced that a $245 \mathrm{~m}$ long test track, with the possibility of supplying three types of voltage - $3 \mathrm{kV}$ DC, $15 \mathrm{kV} 16.7$ $\mathrm{Hz}$ and $25 \mathrm{kV} 50 \mathrm{~Hz}$, was put into operation within its own site [50]. The overhead catenary system is connected to a transformer station, which enables voltage change. The entire system allows the testing of vehicles supplied with voltage other than $3 \mathrm{kV} \mathrm{DC}$, which is used to power the PKP network. Newag launched a similar track with regard to multi-system vehicles or ones manufactured for export. It should be added that a similar track can be found at the Stadler Siedlce plant, with the aforementioned manufacturer carrying out export orders for operators from EU countries.

\subsubsection{Locomotives}

In mid-September 2020, Newag sent the first EU43 Dragon locomotive in the dual-system version ( $3 \mathrm{kV} \mathrm{DC}, 25 \mathrm{kV} 50 \mathrm{~Hz}$ ), manufactured for PKP Cargo, to be tested on the experimental track of the Railway Institute in Węglewo near Żmigród (Fig. 6) [42]. The contract for the supply of 31 vehicles was concluded in September 2019 during the Trako trade fair. According to the agreement, 7 locomotives were to be equipped with an approach module (low-power diesel engine), and the remaining 24 units were to be dual-voltage versions. The requirement for adaptation to operate under a $25 \mathrm{kV} 50 \mathrm{~Hz}$ voltage arises from the need to acquire vehicles capable of moving over the southern part of the railway network in the Czech Republic and Slovakia, which is electrified with alternating current (the northern part is powered by $3 \mathrm{kV}$ DC voltage). Newag intends to deliver 12 dual-system Dragon units in 2021 and 12 in 2022.

At the beginning of October 2020, the first of the 5 ordered Dragon 2 E6ACTab locomotives was delivered to Rail Capital Partners (RCP), a leasing company. The entire contract was to be completed by the end of 2020 ( 2 vehicles received per month) [13]. The value of the new locomotives was PLN $78 \mathrm{~m}$., which amounts to PLN $15.6 \mathrm{~m}$. for 1 unit. RCP intends to acquire a total of 50 locomotives in the coming years.

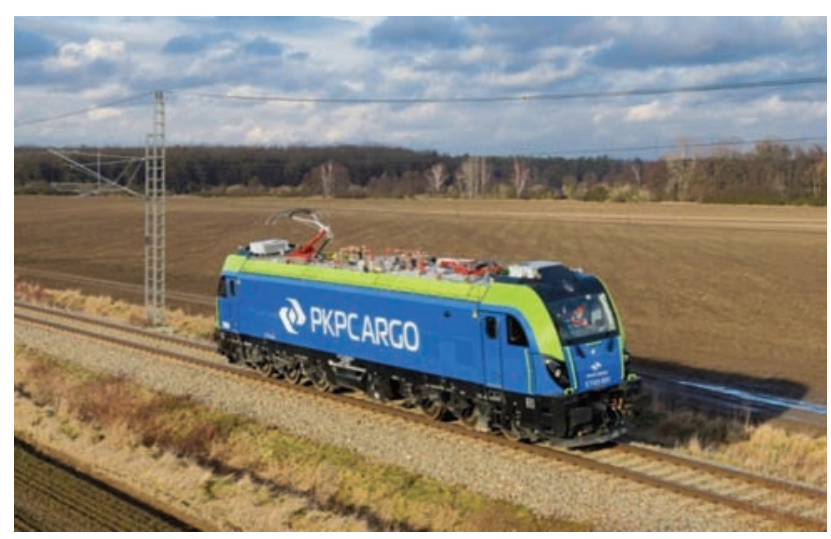

Fig. 6. A Dragon ET43-001 locomotive (Newag; 3 kV DC, $25 \mathrm{kV} 50 \mathrm{~Hz}$ ) during technical and operational tests on the experimental track in Cerhenice near Velim, Czech Republic [photo J. Navratil, 24.01.2021]

In late February 2020, the President of the Polish Office of Rail Transport approved the E4DCU "Griffin" from the EU160 series for operation by PKP IC, in accordance with TSI requirements. The approval is valid indefinitely, without operational restrictions (Fig. 7). The locomotives received a certificate confirming their compliance with the ETCS Baseline 3.4.0 level 2 system, which is a pan-European Train Control System in terms of rail transport interoperability. The certificate enables trains to be freely run within the railway networks of individual countries within the EU, without a requirement to stop at national borders and replace drivers or locomotives. The high power of these locomotives $-5,600 \mathrm{~kW}$, enables the easy movement of passenger trains weighing $800 \mathrm{t}$ with a speed of up to $160 \mathrm{~km} / \mathrm{h}$. In February 2020 , ready vehicles from this series were presented at the central station in Nowy Sącz (8 units in total), and the technical and operational tests were conducted in September 2019 at the track of the Railway Institute in Węglewo near Żmigród. The entire batch was delivered to the PKP IC Central Department and it will ultimately replace the EP09 series in driving passenger trains (EIC, IC, TLK). At the end of June 2020, PKP IC received the last Griffin (EU160 series) manufactured under the basic order covering 20 locomotives and signed in May 2018, valued at PLN $367.6 \mathrm{~m}$. (PLN 18.4 m. per 1 locomotive). Furthermore, an option included in the contract provided for the supply of another 10 vehicles. This was exercised; therefore, the contract value increased to PLN $551.4 \mathrm{~m}$. (loco-

\footnotetext{
${ }^{4}$ Earnings before interest, taxes, depreciation, and amortisation.
} 
motive unit price remained unchanged), so Newag supplied another 10 locomotives ( 30 vehicles in total) by the end of 2020 .

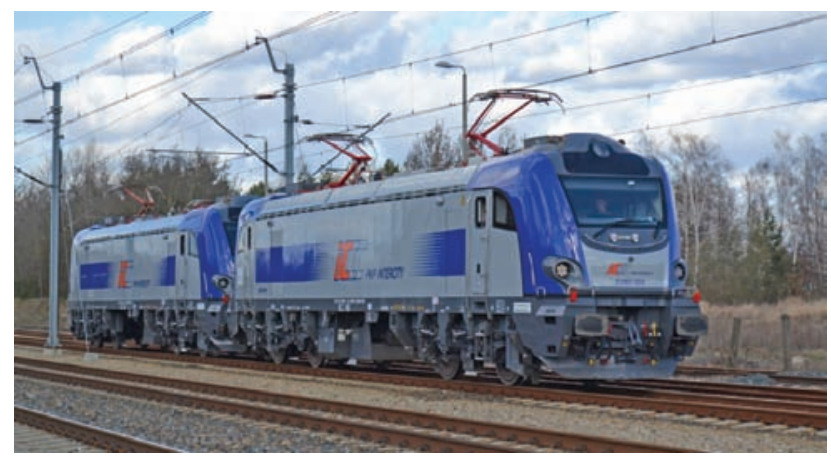

Fig. 7. Griffin EU160-008+007 locomotives (Newag) owned by PKP IC, at Szeligi Station of CMK (Central Railway Main Line) [photo S. Dębski, 11.03.2020]

It should be added that the locomotives were supplied efficiently, at an average of 5 locomotives per month, and the contract was completed in 25 months (2 years) from the date of signature. In late November 2020 , the manufacturer announced the delivery of the last Griffin (EU160-030) locomotive for PKP IC [36]. The operating plan for Griffin locomotives assumed the use of the vehicles for driving IC and TLK trains solely for domestic traffic purposes and on the following lines, starting from the beginning of July 2020:

- TLK Kiev Express on the Warsaw - Kiev - Warsaw route, Warsaw - Dorohusk - Warsaw section;

- IC Zielonogórzanin on the Warsaw - Zbąszynek Warsaw route;

- IC Mewa on the Warsaw - Szczecin - Warsaw route;

- IC Gałczyński on the Warsaw - Szczecin - Warsaw route;

- TLK Staszic on the Warsaw - Kołobrzeg - Warsaw route;

- IC Noteć on the Warsaw - Piła - Warsaw route;

- IC Czartoryski on the Lublin - Zbąszynek - Lublin route;

- TLK Zamoyski on the Piła - Lublin - Piła route;

- TLK Chełmianin on the Warsaw - Chełm - Warsaw route;

- TLK Kochanowski on the Chełm - Bydgoszcz Chełm route;

- TLK Mierzeja on the Lublin - Kołobrzeg - Lublin route, Kołobrzeg - Bydgoszcz - Kołobrzeg section (seasonal);

- TLK Wetlina on the Poznań - Lublin - Poznań section (seasonal);

- TLK Latarnik on the Poznań - Białystok - Poznań section (seasonal);

- TLK Warta on the Warsaw - Poznań - Warsaw route.
PKP IC decided to gradually decommission its EP09 series locomotives, the full withdrawal date being 2027, due to, among other reasons, high P4 repair (revision) costs compared to the EP07 series locomotives. The decision was motivated by the discovered design errors, namely, poor selection of elements transferring tractive and braking forces from the bogies to the body, which led to a lower durability of the main mechanical subassemblies. Although the EP09 series was subjected to major overhauls (P5 level) and modernisation, the fundamental shortcomings were retained or half-way solutions were applied. The faster wear of the mechanical subassemblies in EP09 also stems from the fact that the series was intended for operation at a maximum speed of $140 \mathrm{~km} / \mathrm{h}$, which was later increased to $160 \mathrm{~km} / \mathrm{h}$ - but without significant revisions of the locomotive's design. In addition, the operational characteristics of the EP09 locomotives arise from the rather short times-to-repair, and with a daily mileage ranging from 500 to $1,000 \mathrm{~km}$, individual units would soon qualify for a third major overhaul. Although PKP IC planned a more extensive modernisation of the EP09 series, the idea was ultimately abandoned in favour of purchasing next-gen locomotives.

\subsubsection{Domestic contracts - multiple units}

In early October 2019, the local government authorities of the Pomorskie Province decided to exercise the option for the supply of another four 5-car Impuls EMUs, pursuant to the contract concluded in 2018 and valued at PLN $246 \mathrm{~m}$. (with an option right) [36]. It was initially planned to acquire 5 EMUs, but the positive experience with the new vehicles and the opportunity to receive additional funds resulted in the decision of the Marshall's Office to exercise the option. Impuls 2 units are used to run on the Słupsk - Trójmiasto - Elbląg route, and in the future, after electrification, also in the Pomorska Kolej Metropolitarna (Pomeranian Metropolitan Railway) network. All Impuls units were supplied in Q1 2020.

In mid-November 2018, a contract between the Marshall's Office of the Lubuskie Province and Newag for the supply of two 3-car diesel multiple units valued at PLN $43 \mathrm{~m}$. (PLN $14.3 \mathrm{~m}$. per vehicle), with a delivery deadline by the end of 2020, was concluded [51]. The vehicles, handed-over in mid-November 2020, satisfy TSI requirements and are fitted with ETCS and PZB traffic safety devices, which lets the units enter the DB network to the first border station [64].

In October 2019, Łódzka Kolej Aglomeracyjna (Łódź Metropolitan Railway) received the last of the fourteen ordered 3-car Impuls 2 EMUs [31]. The price of the entire contract amounted to PLN $267 \mathrm{~m}$. (PLN $19.1 \mathrm{~m}$. per EMU), with a co-financing of PLN $164.5 \mathrm{~m}$. (62\%) from the EU's Operational Programme 
for the Łódzkie Province. As of December 2019, it was possible to make the routes and connections listed below available to the public:

- Łódź Chojny - Łódź Olechów - Łódź Widzew;

- Skierniewice - Łowicz - Kutno (number of connections - 26 per day);

- Łódź Fabryczna - Skierniewice: an increase in the number of scheduled connections from 16 to 38;

- Łódź - Tomaszów Mazowiecki: an increase in the number of trains from 2/day to 20/day;

- Łódź Fabryczna - Piotrków Trybunalski: 1 additional pair;

- Łódź - Sieradz: the maintenance of 33 current connections, despite the ongoing route renovation;

- Commencement and termination of connections to/from Łowicz and Kutno at Łódź Widzew;

- Łódź Widzew - Łódź Chojny - Łódź Kaliska ring line: 85 trains/ daily;

- Łódź Widzew - Łódź Stoki - Zgierz and Łódź Łowicz: no changes due to renovation works carried out by PLK;

- Łódź - Warsaw: 9 train pairs on weekends;

- Łódź Fabryczna - Radomsko: 1 extra pair/day.

In December 2019, a contract for the supply of eight 2-car Impuls EMUs was concluded between Newag and the Marshall's Office of the Lubelskie Province. It was priced at PLN $146.6 \mathrm{~m}$. (unit price of PLN $18.3 \mathrm{~m}$.) and has a completion deadline of December 2021 [49]. The contractor also offers a 64-month warranty. In late September 2020, Newag presented one Impuls diesel MU for Koleje Wielkopolskie (Greater Poland Railways), which was sent to undergo technical and operational tests on the Railway Research Institute track in Węglewo near Żmigród [43]. The operator subsequently ordered four $36 \mathrm{Wehd}$ vehicles, pursuant to a contract signed in September 2019 stipulating an option right for two more vehicles [35]. The purchase of four vehicles was co-financed under WRPO (Regional Development Programme for Wielkopolska) 2014+ ("Development of public mass transit in Wielkopolska through the purchase of diesel rolling stock"). The contract value was PLN $94.9 \mathrm{~m}$. (unit price of PLN $23.7 \mathrm{~m}$.), the provided cofinancing was to the amount of PLN $66.4 \mathrm{~m}$., and the delivery time was 410 days for the first two DMUs - and 500 days for the other two. Koleje Wielkopolskie intended to assign the new vehicles to run on the Poznań to Wagrowiec, Gołańcza and Wolsztyn routes. The manufacturer granted a 48-month warranty for each vehicle. The operation of the new DMUs commenced in early November 2020 [61].

At the end of August 2020, Koleje Dolnośląskie (Lower Silesian Railways) concluded a tender for the purchase of two hybrid MUs equipped with electric and diesel drive [47]. The Nowy Sacz-based manufacturer was the only bidder in the tender, and price was the most important criterion. The purchase value for hybrid vehicles was estimated at PLN $56.3 \mathrm{~m}$. or PLN $28.1 \mathrm{~m}$. per unit, which is $50 \%$ higher relative to DMUs and $30 \%$ relative to EMUs. The delivery date was set at 18 months, and the contract includes an option right for 6 more vehicles and the option to order them within 12 months of concluding the contract. In mid-July 2020, Newag also concluded a contract with the authorities of the Zachodnio-Pomorskie West Pomeranian Province for the supply of several hybrid units [44]. The contract involved the supply of two Impuls 2 units of the 36WEh type, with an option right for ten more similar vehicles. The base contract was valued at PLN $40 \mathrm{~m}$., and the additional order was valued at PLN $200 \mathrm{~m}$.

At the end of February 2020, when the operator selected Newag's bid (the only bidder), the tender for the supply of rolling stock for SKM Warszawa was settled. The contract was signed in early April 2020 [22, 34]. In total, Newag's bid covered 21 vehicles, including 15 units -85 to $95 \mathrm{~m}$ long ( 5 cars) - and 6 units -70 to $77 \mathrm{~m}$ long (4 car), together with P1 and P2 maintenace (100\% overhauls) as well as $\mathrm{P} 3$ and $\mathrm{P} 4$ maintenace (60\% overhauls) for 7 years. Newag's bid's value is PLN 543.0 / $667.9 \mathrm{~m}$. net / gross, including the purchase of new vehicles valued at PLN 452.7 / $556.8 \mathrm{~m}$. net / gross plus PLN 77.6 / $111.1 \mathrm{~m}$. net / gross for maintenance. SKM also allotted PLN $779.3 \mathrm{~m}$. for the purchase of new rolling stock. Project completion was set at November 2022 (delivery of the first 2 vehicles was to take place within 23 months of the signature of the contract).

The rolling stock availability factor was determined to be $97 \%$. The manufacturer granted the operator a 4-year warranty for the aforementioned vehicles. The EU funding of PLN $202.6 \mathrm{~m}$. obtained in 2018 came from the Operational Programme Infrastructure and Environment for 2014-2020 Priority V: "Development of rail transport outside of TEN-T". At the same time, it was the largest contract signed to date by both the manufacturer and the operator. In mid-November 2020, the EUR $46 \mathrm{~m}$. (PLN $202.6 \mathrm{~m}$.) co-financing under the Cohesion Fund was approved by the European Commission [74].

In late September 2020, Newag received information from the local government authorities of the Małopolskie Province (Lesser Poland Voivodeship) regarding their intention to exercise the option right for the supply of 2 more Impuls vehicles, pursuant to an amendment to the contract of June 2020. The contract initially provided for the supply of $7 \times 4$-car Impuls EMUs $[45,68]$. Therefore, the contract value increased by PLN $44.78 \mathrm{~m}$. to PLN $199.41 \mathrm{~m}$. (approx. PLN $22.2 \mathrm{~m}$. per vehicle). The time frame for the 
delivery was set for the years 2021-2022. The vehicle purchase obtained EU funding from the European Regional Development Fund. The operator - Koleje Małopolskie (Lesser Poland Railway) - intends to use the vehicles on the following routes:

- Koleje Małopolskie connections:

- SKA2: Skawina - Kraków Gł. - Sędziszów;

- SKA3: Kraków Gł. - Tarnów;

- it is also possible to operate the vehicles on other routes, e.g. SKA1: Wieliczka Rynek Kopalnia Kraków Gł. - Kraków Lotnisko (Cracow Airport);

- alternatively, the vehicles can be assigned to handle transport to Chrzanów, Oświęcim, Wadowice, and Zakopane:

- Kraków Gł. - Nowy Sącz / Krynica Zdrój;

- Przewozy Regionalne connections;

- Kraków Gł. - Katowice.

In early November 2020, Newag handed over 2 SA140 (222Ma type) DMUs to the local government authorities of the Podkarpackie (Subcarpathian) Province, who will offer the vehicles to the Polregio carrier under a lending agreement [69]. The contract for the supply of vehicles was concluded in late July 2019 [48]. Similar vehicles are already in use in the Podkarpacie railway network. They will soon be incorporated into the Podkarpacka Kolej Aglomeracyjna (Subcarpathian Metropolitan Railway), which handles metropolitan and suburban traffic within Rzeszów, including the civilian airport in Jasionka. The aforementioned project was co-financed from EU funds. The manufacturer supplied the new vehicles with a 60-month warranty. Besides diesel vehicles, Newag was to also supply 3-car EMUs from the Impuls 2 family, which will also be operated within the PKA project. The Impuls 2 units will be compatible with the ETCS level 3 system. The value of ordered electric and diesel vehicles exceeded PLN $200 \mathrm{~m}$. In late October 2020, Newag handed over five of the eight three-carriage Impuls 2 EMUs of the 36 Wedb type and EN63B series [72], with the remaining vehicles supplied in mid-December [75]. Until the construction of a new servicing and repair centre in Rzeszów, the Polregio depot in Przeworsk was selected as the Impuls maintenance location (it is an adaptable facility where the EN57 undergoes maintenance).

\subsubsection{Export contracts - multiple units}

In December 2015, Newag concluded a framework agreement for the supply of $15 \times 3$-car Impuls 2 36WEb EMUs for Ferrovie de Sud Est from Italy. In signing this, Newag agreed to supply the 5 first units within 12 months of the date of signature (Fig. 8). The first manufactured EMU was supplied in September 2016 in order to conduct technical and operational tests on the experimental track at the Railway Research Institute in Węglewo near Żmigród. The testing of a second unit and other EMU vehicles manufactured for Koleje Małopolskie took place in late November 2016 at the station in Nowy Sącz. At the turn of November and December 2016, an Impuls 2 was sent to Florence, Italy (HQ location of the ANSF - Italian ORT), where Italcertifer ${ }^{5}$ commenced dynamic EMU tests within the Italian railway network. In mid-July 2017, the manufacturer submitted technical documentation regarding the vehicles in order to obtain an entry into service permit (initially a temporary one - in December 2017). Because FSE changed ownership (in August 2016, the FSE infrastructure was taken over by FS to cover FSE's debts), the contract performance was temporarily suspended.

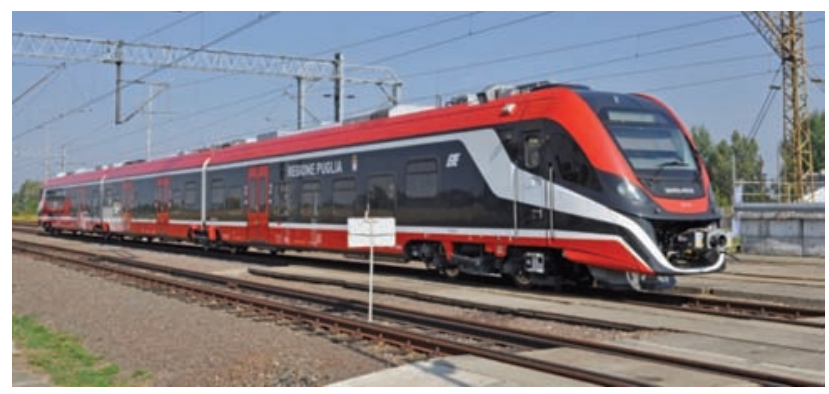

Fig. 8. Impuls 2 36WEb-003 EMU (Newag) for the Ferrovie del Sud Est carrier at the premises of the Railway Institute in Węglewo [photo M. Graff, 06.09.2018]

A complete set of dynamic tests required to obtain ANSF approval was conducted from February to June 2018. A set of documents was submitted in February 2019 and ANSF issued an entry into service permit certificate in mid-May 2019. The public presentation of the vehicle took place in Bari (capital of the Apulia region, where FSE operates) in June 2019. The planned operation of the Impulse units commenced in September 2019, on the Bari - Putignano route. FSE decided to expand the contract by exercising two options: the first covering 6 EMUs signed in May 2019, and the second one concluded in April 2020 and covering 4 units, with a unit price of PLN $17.9 \mathrm{~m}$. and a delivery time frame of 18 months. It should be added that FSE is already operating 27 DMUs of the ATR220 series, manufactured by another Polish producer - Pesa, supplied in the years 2008-2010.

\footnotetext{
${ }^{5}$ Italcertifer offers all basic services in terms of certification and inspection that are required to obtain an operational permit covering railway parts, subsystems, vehicles and infrastructure in accordance with domestic (Italian) and European requirements, especially TSI.
} 


\section{Operational issues of the EP09 series}

The design of the 104E locomotive (later known as the EP09 series) was developed in the years 1979-1980, as a result of collaboration between OBRPS Poznań (currently, Rolling Stock Institute "Tabor") and the Rolling Stock Institute in Novocherkassk (USSR). A design speed of $140 \mathrm{~km} / \mathrm{h}$ was adopted at the engineering stage but the speed requirements were increased to $160 \mathrm{~km} / \mathrm{h}$ at the request of PKP, even though the project had reached the stage of constructing prototypes in 1986-1987. A characteristic feature of the first 7 vehicles was the electrodynamic (ED) brake setting - when braking at a speed of $160 \mathrm{~km} / \mathrm{h}$, it would activate at only $140 \mathrm{~km} / \mathrm{h}$. Currently, in all units, the ED brake works over the full travel speed range. The longitudinal dynamics of the locomotive were also an issue from the very start of operation, and a characteristic pulsed jerking would appear at travel speeds in the range of $100-120 \mathrm{~km} / \mathrm{h}$. This could be felt in the first (and sometimes the second) car behind the locomotive. Such a longitudinal force peak has an impact on the structure. Engineering practices have demonstrated that increasing forces relative to the loads assumed in the design does not have to result in sudden cracking of welded steel structures, however, excessive forces appearing in the course of operation can weaken welded joints and individual structural components, which in turn may lead to fatigue cracking. The effect was thought to be due to the two oblique traction pull rods (front and rear) that were used in each of the bogies. The design of the system is such that only one of the pull rods of a given bogie (tension) would work in a given travel direction.

In the second half of the 1990s, the issue of longitudinal dynamics concerning the locomotive, as well as increasing the durability and reliability of the drive unit (especially the traction gear) was addressed by numerous institutions, including OBRPS Poznan (the author of the design documentation - currently, the Rolling Stock Institute "Tabor" Poznań), Warsaw University of Technology, and Cracow University of Technology. Many solutions were proposed but most of them were never adopted in practice. A solution which many hoped would improve the longitudinal dynamics involved a change of the secondary suspension. Thus, a new body support system using large-size flexicoil springs was designed in 1994-1995. The positive outcomes of the tests carried out with the new solution enabled departure from a dropper system that required periodic adjustments and an interbogie coupling solution. Despite the positive operational test results (conducted by CNTK Warsaw, currently the Railway Research Institute), the pulsed jerking effect still occurred. The causes behind the problem have still not been identified to date, and the effect of cars being jerked about by the locomotive still appears. Until a few years ago, the intent was to modernise the vehicles to allow speeds of $180-190 \mathrm{~km} / \mathrm{h}$ (which until recently was the conventional vehicle approval limit) - raising the speed to $200 \mathrm{~km} / \mathrm{h}$ would result in the approval for a high-speed vehicle, which would significantly increase project costs. The scope of changes was to be broad, and included increasing the traction power (new asynchronous motors) and ED braking power, the use of monoblock wheelsets, disc brakes, new shock absorbers, inclusion of impact energy absorbing elements, and a new frontal aspect to enhance aerodynamics. However, ultimately, due to the extensive scope and costs that were close to the price of a new vehicle, the project was abandoned.

\subsection{Pesa}

Pesa, formerly ZNTK (Rolling Stock Repair Plant) Bydgoszcz, was the first entity to commence the manufacturing of lightweight diesel rolling stock for Poland's regional operators, as well as of electric rolling stock in which three-phase drive and other modern solutions were incorporated. The current offering of the company includes, among others, the Elf 2 EMU and Gama locomotives (electric and diesel) - Figs. 9 and 10. It seems that, apart from diesel rolling stock, the company's success might have been determined by commencing the production of trams, initially for Polish carriers, and later for export. Some of the first foreign orders included contracts for Italian operators for the supply of 3-car Atribo DMUs (with Trenitalia as one of the clients). After the financial turmoil associated with entering the difficult German market (Link DMUs ordered for DB Region and other entities), Pesa was restructured, nationalised, and taken over by the Polish Development Fund (PFR). Currently, the Bydgoszcz-based manufacturer has a plant in Mińsk Mazowiecki, which carries out repairs of passenger trains, and deals with the servicing and maintenance of EMUs operated by selected carriers (including PKP IC and SKM Warsaw). The core of Pesa's export production is $1,520 \mathrm{~mm}$ track gauge rolling stock (contracts implemented for LG, BC and UZ, as well as individual contracts for RZD and KTZ). Besides manufacturing vehicles, Pesa also repairs and modernises rolling stock (diesel locomotives, passenger cars).

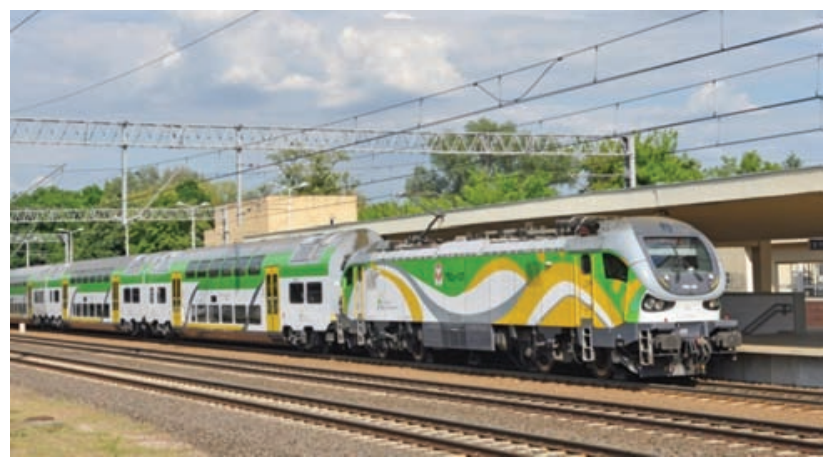

Fig. 9. Gama 111Eb-001 locomotive (Pesa) at Pruszków Station [M. Graff, 04.06.2021] 


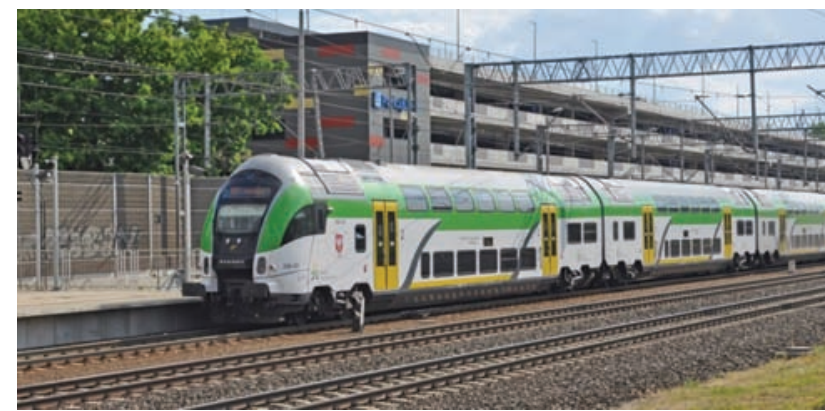

Fig. 10. Double-deck control carriage of the 316B type (Pesa) [photo M. Graff]

In late September 2020, Pesa's management announced the completion of overdue contracts from 2014-2016 in Q3 2020, often with a loss [52]. The financial results of the manufacturer for 2019 were as follows:

- sales revenue - PLN 1.2 bn - 22\% higher relative to 2018 ;

- production volume in 2020 was $60-70 \%$ higher compared to 2019;

- operational loss was reported; however, it was just partially of a monetary nature and did not result in a loss of solvency or a threat to continued operation;

- EBITDA (earnings before interest, taxes, depreciation and amortisation) for 2018 of PLN $-508 \mathrm{~m}$. was caused by increased risk and the need to create provisions for liquidated damages on account of potential contract performance delays, e.g. contract with SKM Warsaw, terminated in February 2020;

- EBITDA for the first half of 2020 amounted to PLN 10 m.;

- the order portfolio's value is approx. PLN 3 bn, with new orders being secured;

- access to bank financing was obtained only in 2020 (PFR financial aid was used previously), which should mitigate issues with orders for subassemblies and components, contributing to manufacturing smoothness;

- Pesa's audit for 2019 ended with a positive result;

- issues with financial liquidity have been eliminated and Pesa's financial situation is deemed stable;

- vehicles are manufactured in a timely manner;

- the company has been undergoing restructuring since 2017, which involves employment optimisation, administrative staff lay-offs, and potential employee transfers to manufacturing (e.g. recruitment launched) or support for people leaving Pesa;

- in November 2018, the Investment Fund for Polish Enterprises (FIZAN) took over the control of Pesa, while some part of the investment portfolio is managed by the Polish Development Fund.

\subsubsection{Locomotives}

In July 2020, Pesa concluded a contract for the delivery of a single Gama locomotive - in its electric ver- sion, with an auxiliary approach engine in the 111Ed version, for Pol-Miedź Trans [37]. The contract value is PLN $14.39 \mathrm{~m}$. net, and the time for completion is 24 months. The purchase was co-financed from EU funds within the framework of the "Purchase of new flatcars and a locomotive for carrying cargo in intermodal transport by Pol-Miedź Trans Sp. z o.o. in Lublin" under the Operational Programme Infrastructure and Environment 2014-2020 (application qualification process conducted by CUPT).

\subsubsection{Domestic contracts - multiple units}

In April 2019, the management of Koleje Sląskie (Silesian Railway) decided to expand a then-current contract by ordering two more 3 -car vehicles. The last 4-car unit was received in early May 2019, and the last ordered Elf 2 EMU was supplied in late May 2020.

At the end of October 2019, the local government authorities of the Małopolskie Province concluded a contract with Pesa for the supply of four Elf 2 EMUs, valued at PLN $109.7 \mathrm{~m}$. (PLN $27.4 \mathrm{~m}$. per vehicle) [40]. The ordered units met the relevant TSI requirements and the contract value also covered the provision of maintenance services for 5 years, including maintenance at the P4 level. The new EMUs will expand the rolling stock assets already operated by Koleje Małopolskie, used for transportation within the Kraków metropolitan area and on outbound routes from the city to Tarnów, Sędziszów, Wieliczka, Balice Airport, and Skawina. The operator's managing authorities estimate the daily mileage of the already operated EMUs to be at $500 \mathrm{~km}$, and that the operational availability indices of the new-gen units will reach a level of at least $98 \%$.

In mid-February 2020, Pesa concluded a contract for the supply of five 5-car Elf 2 vehicles, with an option for two more EMUs for Poznańska Kolej Metropolitarna (Poznan Metropolitan Railway), namely, to offer transportation services on 9 outbound routes from Poznań to the stations of: Wronki, Kościan, Rogoźno, Nowy Tomyśl, Jarocin, Września, Gniezno, Grodzisk Wielkopolski, and Wągrowiec (by default, up to $50 \mathrm{~km}$ from Poznań) [54]. The contract was valued at PLN $127.45 \mathrm{~m}$. (PLN $25.5 \mathrm{~m}$. per vehicle), including PLN $48.75 \mathrm{~m}$. co-financed (38\%) from the EU's OPI\&E 2014-2020 programme. The operator had its new vehicles supplied from June to December 2020. They satisfy TSI requirements and are suitable for installation of the ETCS level 3 system.

At the end of September 2020, Pesa signed a contract for the supply of five Elf 2 EMUs for Koleje Dolnośląskie, with a delivery deadline of July 2022 [79]. The contract is valued at PLN $145 \mathrm{~m}$. (PLN $29 \mathrm{~m}$. per unit), and it also covers vehicle maintenance at level P3 inclusive. In addition, it provides for an option of expanding the order to 25 EMUs, with 
a deadline for exercising the option of 12 months from concluding the deal. PLN $85.1 \mathrm{~m}$. (59\%) for the purchase of the new rolling stock was allocated from the Centre for EU Transport Projects under the Project "Metropolitan Railway in Lower Silesia - purchasing rolling stock to handle passenger traffic within the Wrocław Functional Area". The sections planned to make use of the new rolling stock are Wrocław - Jelcz Laskowice along two routes - via Wrocław Wojnów or Siechnice, with a possible extension to Oleśnica. Additional funds for the purchase of EMUs were obtained from two bank loans granted by mBank - the first loan of PLN $170.42 \mathrm{~m}$. for purchasing the vehicles, and the second loan of PLN $58.75 \mathrm{~m}$. on account of VAT.

\subsubsection{Export contracts - multiple units}

Another export contract carried out by Pesa is one for the supply of 3-cars ATR220Tr DMUs for several Italian operators [67]. One of them is Trenitalia, which had already concluded another contract for the supply of 14 additional vehicles in March 2018, by exercising the option right under the contract of November 2013. In total, the Polish manufacturer has already produced 85 vehicles of this series: 41 / 44 vehicles in the older / newer ATR220 / ATR220Tr version that are operated on local routes in the regions from northern Lombardy to southern Apulia. Currently, the ordered DMUs have been allocated by the carrier to run on Sardinia, which is the largest Italian island in the Mediterranean Sea. Vehicle deliveries were expected to end in January 2021.

In March 2019, Pesa concluded a first export contract for the supply of Elf 2 units (Elf.eu version) for RegioJet, an operators from the Czech Republic. The contract covered seven 2-car EMUs valued at CZK 1.5 bn (PLN 245 m., which is PLN $35.1 \mathrm{~m}$. per vehicle), which are intended to run on regional lines in the Ustí nad Labem area [16, 41], as RadioJet was awarded a contract to manage the route for 10 years. The Elf 2 units for RegioJet will come in the dual-voltage version - $3 \mathrm{kV}$ DC and $25 \mathrm{kV} 50 \mathrm{~Hz}$ - with both voltages used in the region. It should be noted that $\check{C} \mathrm{D}$ is ultimately planning a voltage conversion from $3 \mathrm{kV}$ DC to $25 \mathrm{kV} 50 \mathrm{~Hz}$, which is used in the northern and southern parts of the country. The EMUs will be suitable for the installation of ETCS level 2 traffic safety system equipment. The Elf purchase contract also covered warranty repairs for 24 months and provided for the purchase of maintenance services. The EMUs will be operated on the following routes:

- Ústí nad Labem - Střekov (line U7);

- Ústí nad Labem - Úpořiny - Bílina (line U5);

- Most - Žatec (line U13);

- Most - Žatec / Bílina, Ústí nad Labem - Štětí and Teplice - Litvínov (some routes).
It should be added that this is the first RegioJet contract for the provision of public services in the Czech Republic. The units should be delivered and obtain an entry into service permit for both voltages by the end of 2021. The new Elfs will replace the previously operated VT628 DMUs purchased from DB. Pesa's representatives noted that the Czech Republic is becoming a gateway to Europe for the Bydgoszczbased manufacturer - ČD was the first carrier to order Link DMUs, and that experience was later used to win a contract with DB Regio for the supply of several dozen Link units, both 2- and 3-car.

In mid-July 2019, Pesa delivered the first 6-car DMU of the $760 \mathrm{M}$ series (or DP6), with a total power of $2350 \mathrm{~kW}$, for Belarusian Railways (BC) (track gauge $1520 \mathrm{~mm}$, Figure 11) [73]. BC ordered 6 similar vehicles as part of transport development in the years 2016-2020, and the funds were provided by state-owned banks as leasing. The manufacturer delivered 3 vehicles in 2019 and 3 in 2020. These are DMUs with each car resting on individual bogies (Jacobs bogies were abandoned). The vehicles are adapted for service on low platforms (additional step for passengers added). The $760 \mathrm{M}$ series is a step-up for the $730 \mathrm{M} / 731 \mathrm{M}$ series, already delivered by Pesa to $\mathrm{BC}$ and already used by the operator to run on IC routes, especially on non-electrified lines (including from Minsk to Vilnius), e.g. Minsk - Grodno, Minsk - Polock, Mogilev - Gomel, Mogilev - Polock and others. Purchasing the DMUs is an element of a scheme aimed at departing from the use of classic trains (locomotive + car) on daily routes in favour of multiple units. Regular operation of the $760 \mathrm{M}$ series commenced in December 2019 on the Minsk - Orsha - Vitebsk route (the Minsk - Orsha section is electrified) as trains with a business class and a travel time of $3 \mathrm{~h}(296 \mathrm{~km}$, not stopping at intermediate stations) or $3 \mathrm{~h} 16$ minutes (with stopovers at Bogushevsk, Orsha, Talachyn, and Barysaw) [53]. It should be added that a classic night train journey on this route takes around 6 hours (it is necessary to change locomotives at Orsha). The DP6 series vehicles reach a maximum speed of approx. $140 \mathrm{~km} / \mathrm{h}$ (speed on this route $-135 \mathrm{~km} / \mathrm{h}$ ). The DP6 has 311 $2^{\text {nd }}$-class seats and $251^{\text {st }}$-class seats. Train occupancy varies from $70 \%$ to $100 \%$. The trains are airconditioned, have Wi-Fi access, sockets for charging mobile phones, vacuum toilets, and seats for people with disabilities. The approval of DP6 vehicles was based on the Technical Regulation TR TS 001/2011 of the Eurasian Economic Union, therefore, similar DMUs can theoretically be offered to carriers in Russia, Lithuania, Uzbekistan, Kazakhstan, or Moldova. The manufacturer will service the new vehicles for a period of 3 years. No option for purchasing more vehicles was granted. 


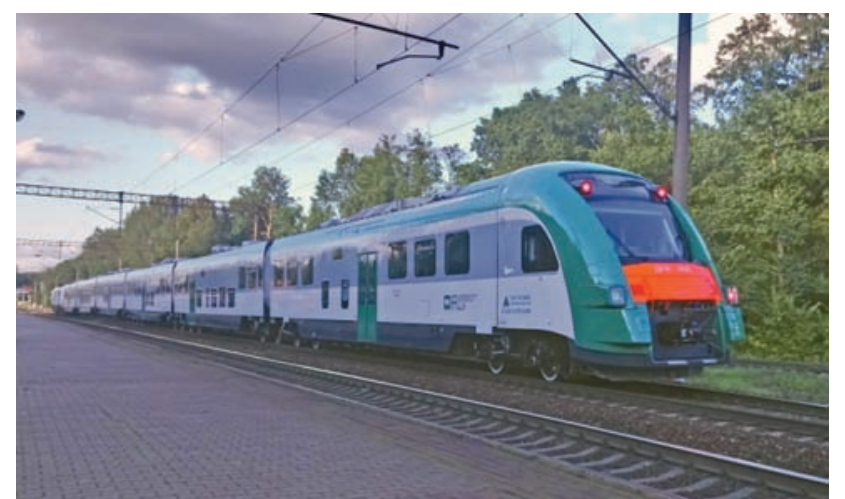

Fig. 11. DMU of the DP6/760M-006 series (Pesa, $1520 \mathrm{~mm}$ ), BC railway, Minsk suburbs [photo S. Badionkin, 04.09.2020]

Contracts for the supply for $\mathrm{BC}$ or an operator from a non-EU country cannot be co-financed from EU funds (OPI\&E, CEF, etc.). It is therefore necessary to obtain financial aid in a different way, e.g. through Santander Group and KUKE (financing and insurance $)^{6}[24]$. The vehicles were purchased by a leasing company belonging to a state-owned Belarusian bank as the transaction guarantor. The Santander Group provided the Belarusian party with funds for financing the vehicle purchase, and KUKE is an entity supporting Polish exporters on behalf of the State Treasury. For this reason, the 6-year loan is insured, which protects the bank against defaults or delays in payments in the event of a commercial or political risk. In the case of the contract for DP6 vehicles, Pesa received EUR $32 \mathrm{~m}$. from the Santander Group and KUKE. The Santander Group is a global leader in providing financing insurance services for export supporting agencies. It should be added that previous supplies by Pesa for BC in 2013, 2016 and 2019 were implemented in a similar manner.

At the end of September 2020, the Bydgoszczbased manufacturer delivered the last Link DMUs to DB Regio (Fig. 12). They were supplied to the Bavarian branch of the carrier (based in Kempten) [55]. In total, Pesa delivered 72 vehicles for DB (the framework agreements from September 2012 provided for a supply of up to 420 units), including $23 \times 2$-car and $49 \times 3$-car vehicles, designated as 632 and 633 series, respectively. The operator allocated the Link units to handle regional traffic in the regions of Dortmund / Sauerland, Frankfurt / Hesse / and Munich / Allgäu / Bavaria. Supplying vehicles to the demanding German market was a huge challenge for Pesa, and the difficulties that arose were solved by an established Polish-German group responsible for the entire contract - from the design through production to initial approval of the vehicles. Link units were purchased by DB and NEB, while Regentalbahn ultimately withdrew from the deal due to the prolonged entry into service approval process (finally obtained in May 2018). The Link units purchased by DB have a maximum speed of $140 \mathrm{~km} / \mathrm{h}$, while the number of passenger seats varies from 110 to 160 (1st class -12).

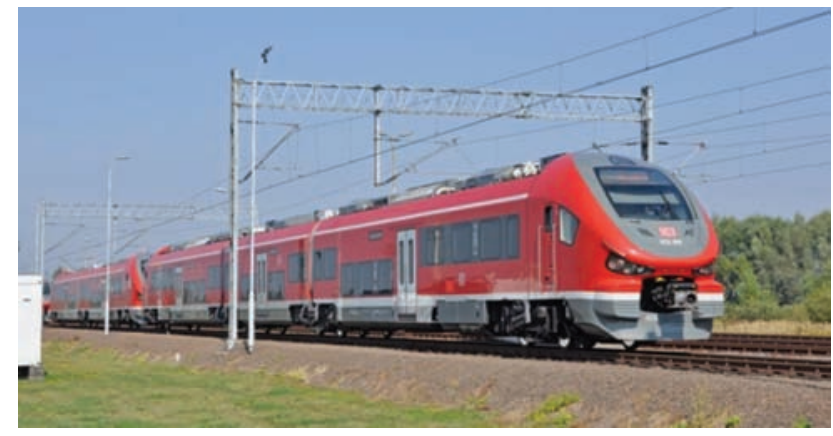

Fig. 12. DMU of the 633-001 series (Pesa) for DB Regio at the experimental track of the Railway Research Institute in Węglewo near Żmigród [photo M. Graff, 06.09.2018]

The essential difference between approving vehicles for traffic in Germany and in Poland is the vast experience of EBA, the German ORT, as well as long-standing regulations and procedures that have evolved (e.g. a fixed 3-year period from contract conclusion to final entry into service approval). In Poland, after the crisis in 1989 , the state was practically unable to help domestic manufacturers (an example is the termination of electric and diesel locomotive manufacturing by $\mathrm{H}$. Cegielski in 1994), and new entities after 2000 had to gain experience on their own, usually via the trial-anderror method, just like contemporary producers. These were largely new companies that had not been previously involved in the industry. Poland's accession to the EU in May 2004 provided an opportunity to receive EU financial support in individual fields of the Polish economy, including the railway sector, and a strong impetus to launch a broad railway modernisation scheme in Poland. This involved infrastructure overhauls and purchasing modern rolling stock.

The Bydgoszcz-based manufacturer tried to adapt to the situation, and the poor financial resources initially available to local governments and the lack of clear rules to be satisfied by new vehicles meant that both parties saved heavily with regard to the offered technical solutions, servicing and repairs. Pesa's entry into the German market, where any "shortcuts" were out of the question, and its encounter with EBA, i.e. very meticulous officials who thoroughly study a vehicle's technical documentation, was a great challenge. Fortunately, as

\footnotetext{
${ }^{6}$ KUKE Finance, a factoring company, was established by the Export Credit Insurance Corporation (KUKE) in 2014.
} 
shown in practice, it was ultimately overcome, despite numerous difficulties (e.g. issues with financial liquidity and, ultimately, nationalisation). It should be added that many manufacturers who have long been present in the German market, e.g. Stadler, Bombardier and Alstom, have experienced the effects of EBA's inquisitiveness. It should also be underlined that Pesa is currently the only manufacturer from Poland admitted to the German market. The experience gained in engineering and manufacturing Link units for this market will certainly pay off in the future and facilitate the preparation of new export contracts.

\subsubsection{Rolling stock modernisation}

At the end of July 2020, Pesa supplied 83 modernised 111A-20 non-compartment car to PKP IC under a basic contract signed in April 2018 and valued at PLN $312 \mathrm{~m}$. [38]. The retrofitting was carried out by two Pesa plants - in Bydgoszcz and Mińsk Mazowiecki. A total of 245 cars modernised for the operator at the cost of PLN 1.03 bn was planned. A contract for another 42 car under the contract option was concluded in November 2018. It was valued at PLN $158 \mathrm{~m}$. and provided for delivery in the second half of 2020. According to the contract, the modernising entity should also conduct P3-level technical inspections of cars. The "Accelerating comfortably" project is co-financed from EU funds. PKP IC intends to integrate the modernised carriages in the following trains:

- IC Albatros on the Gdańsk - Szczecin - Gdańsk route;

- IC Żuławy on the Szczecin - Olsztyn - Szczecin route;

- IC Jeziorak on the Olsztyn - Poznań - Olsztyn route;

- IC Ukiel on the Olsztyn - Zielona Góra - Olsztyn route;

- IC Stoczniowiec on the Zielona Góra - Gdynia Zielona Góra route;

- IC Gryf on the Szczecin - Olsztyn - Szczecin route;

- IC Drwęca on the Olsztyn - Poznań - Olsztyn route;

- IC Lednica on the Poznań - Gdynia - Poznań route;

- IC Bachus on the Gdynia - Zielona Góra - Gdynia route;

- IC Bolko on the Lublin - Szczecin - Lublin route;

- IC Sztygar on the Wrocław - Lublin - Wrocław route;

- IC Morcinek on the Wrocław - Lublin - Wrocław route;

- IC Jagiełło on the Lublin - Kraków - Lublin route;

- IC Hetman on the Wrocław - Lublin/Hrubieszów - Wrocław route;

- IC Mamry on the Wrocław - Białystok - Wrocław route;
- IC Rybak on the Białystok - Szczecin - Białystok route;

- IC Pomorzanin on the Wrocław - Gdynia - Wrocław route;

and from August 2020:

- IC Gałczyński on the Warsaw - Szczecin / Gorzów Wielkopolski - Warsaw route;

- IC Mewa on the Warsaw - Szczecin - Warsaw route;

- IC Zielonogórzanin on the Warsaw - Zielona Góra - Warsaw route;

- IC Inka on the Warsaw - Lublin - Warsaw route;

- IC Czartoryski on the Lublin - Zielona Góra - Lublin route;

- IC Starzyński on the Warsaw - Terespol - Warsaw route;

- IC Żubr on the Warsaw - Piła - Warsaw route;

- IC Noteć on the Piła - Warsaw - Piła route.

Pesa also repairs locomotives, especially of the older type, which owing to their design simplicity is not difficult. In July 2020, Pesa and PKP Cargo agreed to reduce the number of ST44 level P5 repairs due to declining transport, which also means a reduction in the rolling stock demand [39]. The scope of repairs covers replacing the locomotives' diesel engines, while the number of vehicles will be reduced from 38 to 25 . The deadline, pursuant to an amendment to the contract of May 2018, was extended until the end of May 2021. The contract value was PLN $116 \mathrm{~m}$. Extending the contract performance date was also important for the modernising entity since the COVID-19 pandemic lasting for several months in 2020 disturbed the collaboration with vendors.

\subsection{Siemens}

Siemens, a global concern from Germany, although without their own plant in Poland, has established various consortia with other manufacturers, e.g. Newag, for the purposes of supplying rolling stock (e.g. the Inspiro trains for the Warsaw underground or exported Inspiro for the Sofia underground). Siemens has manufactured, among others, the Husarz (Taurus) locomotives for PKP IC and Vectron for PKP Cargo and DB Cargo Polska, primarily for use in passenger and freight transport between Poland and Germany (Fig. 13 and 14). It has also supplied Combino trams for MPK Poznań. Siemens, like Alstom or Bombardier, does not participate in tenders involving EMUs for Polish carriers because one of the key criteria is the vehicle price (and not e.g. operational availability) ${ }^{7}$.

\footnotetext{
${ }^{7}$ Although Stadler participates in similar tendering procedures, it does so for only large carriers, e.g. PKP IC or Koleje Mazowieckie (an order for several dozen EMUs, with a minimum of 10 vehicles).
} 


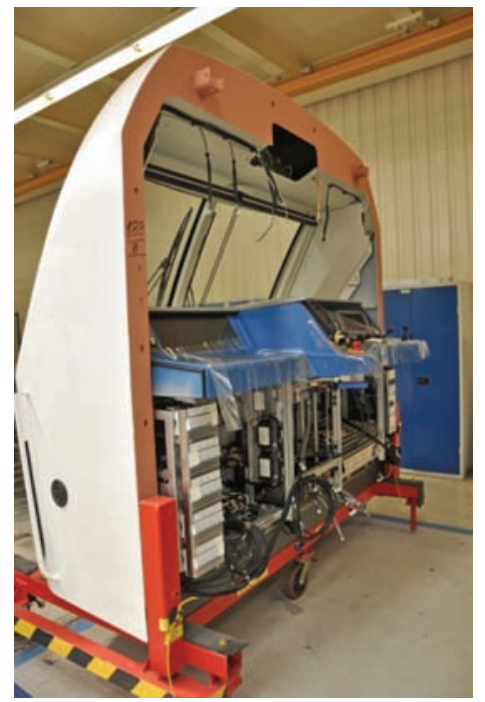

Fig. 13. Vectron locomotive driver cabin, Allach plant [photo M. Graff, 27.06.2016]

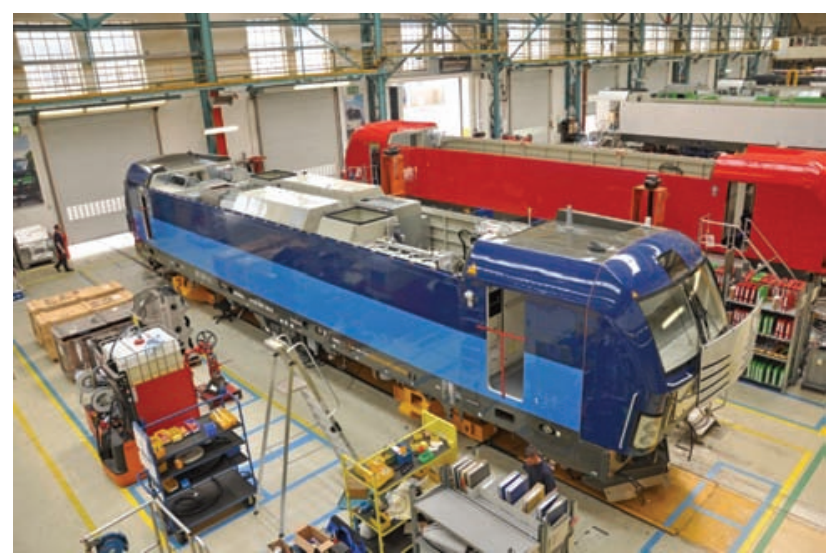

Fig. 14. Vectron (Siemens) locomotives during assembly, factory Allach, Munich [photo M. Graff, 27.06.2016]

In mid-July 2019, PKP Cargo, which is the largest rail freight operator in Poland and the second biggest in Europe (after DB Cargo), received 3 new Vectron MS locomotives manufactured by Siemens Mobility. As a result, PKP Cargo's Vectron fleet has increased to 20 units.

In September 2015, the operator obtained its first 15 Vectron MS locomotives and it exercised an option for 5 more vehicles in January 2019 - six months later, it received the first 3 Vectron units, with 2 more handed over in early 2020. The purchased locomotives have a power of $6,400 \mathrm{~kW}$, a maximum speed of $160 \mathrm{~km} / \mathrm{h}$, are equipped with the ETCS system and have been approved for operation on the railway networks of Poland, Germany, Austria, the Czech Republic, Slovakia, Romania, and Hungary. It should be noted that Vectron platform vehicles can run in as many as 18 European countries (depending on the locomotives being equipped with the approved national safety systems). PKP Cargo intends to use Vectrons to handle routes within the New Silk Road (NSR) and the so-called Three Sea countries. A long-term goal of the operator is achieving the position of intermodal transport market leader in the Three Seas Initiative area and the EU NSR section.

Vectron locomotives are adapted to crossing European railway borders without stopping (a difference compared to e.g. the EU44 / ES64P4 locomotives operated by PKP IC). Eliminating the need to stop at the border shortens passenger train travel time by several minutes, and even up to half an hour for a freight train, while simultaneously lowering the costs involved in rolling stock operation and reducing the necessary driver work time. Over the last several years, Siemens Mobility has sold over 900 Vectron locomotives, and the supplied vehicles have already covered more than 215 million kilometres. Similar locomotives are operated within the PLK network (besides PKP Cargo) by DB Cargo Polska, Industrial Division and operators from Germany, the Czech Republic and Austria. Furthermore, a Vectron belonging to MRCE (a rented vehicle) heads trains owned by PKP Intercity. In order to present the aforementioned capabilities of Vectron locomotives, the manufacturer - in collaboration with the operator organised a test run in July 2019 on the Chojnów - Węgliniec - Bielawa - Horka route, across the Polish-German border (the train was headed by EU46514), after the PKP-DB Bielawa - Horka border crossing was electrified in December 2018 (change of voltage $3 \mathrm{kV} \mathrm{DC} \leftrightarrow 15 \mathrm{kV} 16.7 \mathrm{~Hz}$ on the German side).

In early July 2019, Siemens Mobility and Newag signed an amendment to the contract for the supply of 100 additional ETCS onboard devices for vehicles manufactured by Newag. It is an extension to the framework agreement between both companies regarding the supply of onboard devices. The new systems will be installed in, among others, Dragon 2 locomotives so as to gain approval for running on both Polish and other European rail systems. It should be added that, since 2016, Siemens Mobility has supplied almost 200 Trainguard ETCS onboard devices for locomotives and electric multiple units manufactured by Newag. Beyond this, the companies have signed an amendment to the applicable contract that extends the supplies by an extra 100 units. The supplied Siemens solutions are compliant with the latest European regulations in terms of ETCS level 3 baseline 3. Siemens onboard devices are also compact and virtually maintenance-free, and the German manufacturer has vast experience in integrating ETCS with the individual national safety systems put in place by EU operators. The currently valid amendment extends the contract validity date until the end of 2023 and leads to the unification of the onboard part of ETCS systems installed in Newag vehicles, while reducing the time required for their full implementation. 
The metro in the capital of Bulgaria ordered twenty 3-car Inspiro underground trains for line no. 3, similar to their equivalents operated by the Warsaw underground. Underground cars were manufactured as a joint effort of Siemens and Newag, and the main and auxiliary converters were supplied by Medcom. The advertised technical data includes: carriagelayout D-T-D, body sheathing - aluminium, track gauge $1,435 \mathrm{~mm}$, total length $60,008 \mathrm{~mm}$, maximum width $2,650 \mathrm{~mm}$, floor height above rail head $1,100 \mathrm{~mm}$, axle load $12 \mathrm{t}$, maximum speed $80 \mathrm{~km} / \mathrm{h}$, door width $1,400 \mathrm{~mm}$, supply voltage $1.5 \mathrm{kV}$ DC from an overhead contact line, and places for passengers: 110 seats and 617 standing spots. Train deliveries were to start in July 2018, pursuant to a contract concluded in 2015.

\section{9. Škoda}

Škoda, a manufacturer from the Czech Republic, supplied the EU/EP05 passenger locomotives produced under a Swiss license, which started electric traction in Poland. It also supplied the ET40 series for freight traffic. Currently, the Pilzno-based manufacturer is conducting a contract for the design and manufacturing of underground rolling stock for Warsaw, with manufacturing taking place in the Czech Republic (Figures 15 and 16).

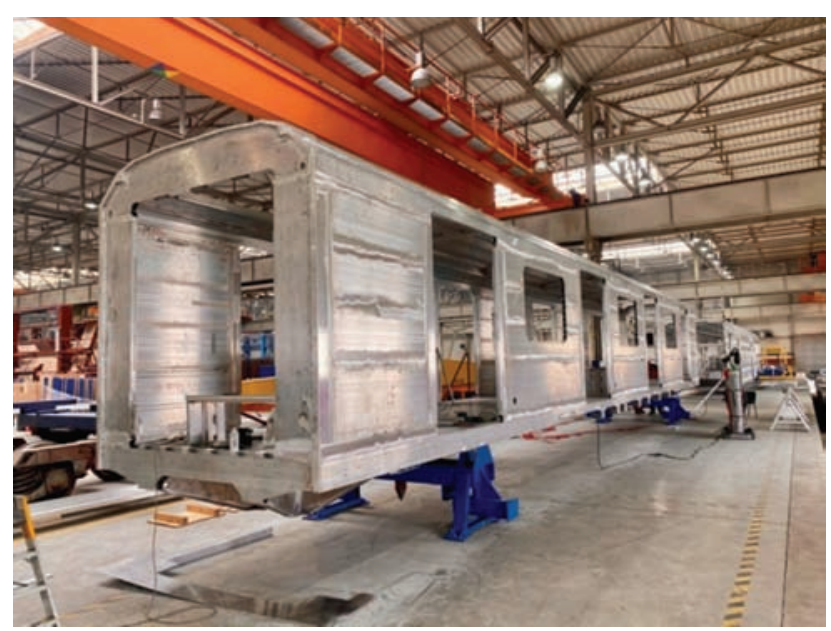

Fig. 15. Aluminium body for a Warsaw underground train [photo M. Tobrman / Škoda]

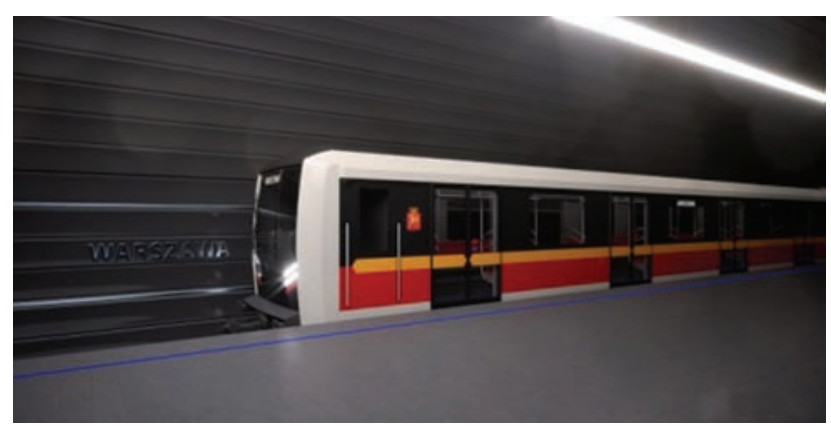

Fig. 16. Animation of a Warsaw underground train [photo M. Tobrman / Škoda]
In late January 2020, the Czech concern Škoda (Škoda Transportation and Škoda Vagonka) and Metro Warszawskie signed an agreement valued at PLN 1.31 bn for the supply of $45 \times 6$-car trains (including 8 optional units). The ordered trains will be used to handle rolling stock on line no. 2 , which is currently being expanded in both directions (western and north-eastern) and line no. 1, where, according to the operator intention, they will replace the currently operated series 81 cars of Soviet and Russianbuilt. The first Škoda trains should be delivered within 20 months of the date of the contract being signed, and the last train - within 53 months of the said date. The operator will receive funds for the purchase of new rolling stock from, among others, two EU aid programmes: "Construction of the $2^{\text {nd }}$ underground line with associated infrastructure and rolling stock purchase - stage II" and "Construction of the $2^{\text {nd }}$ underground line with rolling stock purchase - stage III". When evaluating the bids of manufacturers participating in the tender, the committee considered such factors as price (50\%), electricity consumption (24\%), vehicle maintenance costs $(22 \%)$ and environmental issues (4\%). The metro fleet will be manufactured in Škoda plants in Ostrava (among others, bodies) and Pilzno (electrical and mechanical parts plus final assembly). They will be single-space trains, equipped with an energy recuperation system, adapted to transport physically disabled people. One of Škoda's advantages were the long times between repairs equal to 130 days (4 months). In comparison, a similar index for Inspiro by Siemens is 2 months, Alstom's Metropolis - 2 weeks and the $81 \mathrm{MMZ}$ / Vagonmash series $20 \mathrm{~h}$. Although Škoda has not yet independently and serially manufactured underground car, it has been involved in underground rolling stock modernisation in Prague, Kiev and Tbilisi (cars of the 81 series, after modernisation of $81-71 \mathrm{M}$ ), and has designed and manufactured Newa cars for the Saint Petersburg underground, based on the 6Mt series. Currently, the Czech company is the co-owner of a manufacturer from St. Petersburg - Vagonmash (51\% of shares) that deals with the Kirov Factory (49\% of shares).

\subsection{Stadler}

Stadler is an international concern from Switzerland and operates in the EU, North America, and several post-Soviet states. In 2007, Stadler constructed a completely new plant in Siedlce, Poland, and supplied its flagship product - the Flirt MU - to several Polish operators (via a framework agreement with Koleje Mazowieckie, Mazovia Railway). It is also currently implementing export orders for several European operators (track gauge $1,435 \mathrm{~mm}$ vehicles). Recent orders cover the supply of trams for 
MPK Kraków. These are being manufactured outside the Siedlce plant, in Środa Wielkopolska, where the plant acquired from Solaris in 2018 is located. Although Stadler manufactures a wide range of rolling stock (underground, locomotives, high-speed trains), orders implemented in Poland involve only MUs and trams.

In mid-September 2020, Stadler commenced the production of 12 Flirt units (Fig. 17) ordered by PKP IC under a PLN 1.02 bn contract concluded in 2019. This also involves EMU maintenance for 15 years [60]. Manufacturing takes place in the plant in Siedlce, and each vehicle is assembled in the following manner:

- body installation - assembly of the electrical and pneumatic parts, insulation, and fastenings;

- installation of wall, floor, or ceiling elements;

- installation of vehicle lighting and equipment: seats, tables, shelves, etc.

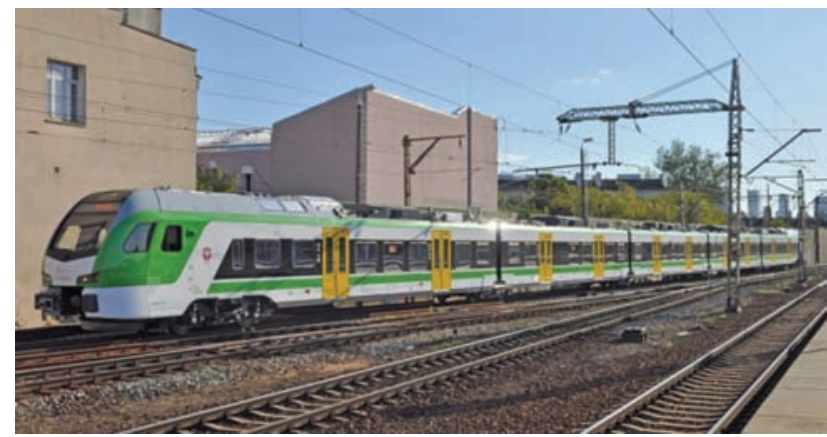

Fig. 17. The Flirt EMU of the ED160-10A series (Stadler), owned by Koleje Mazowieckie and used as a passenger train on the Sochaczew - Dęblin route, calling at Warszawa Wsch. Station [photo M. Graff, 15.08.2020]

Flirt bodies for all Stadler group vehicles are manufactured in Hungary out of aluminium. It is a process which is more difficult compared to the manufacturing of the bodies' steel equivalents (welding of aluminium elements must take place in an anaerobic atmosphere). Despite the greater thickness of aluminium sheets, owing to currently available technologies, the aluminium bodies are lighter than their steel equivalents. Moreover, the poorer acoustic wave conductivity of aluminium relative to iron / steel also means better acoustic insulation. Furthermore, the lower EMU mass means not only lower energy consumption, but also lower wear of the mechanical part of the railway infrastructure. Flirt units satisfy the current European crashworthiness (EN 15227) and durability (EN 12663) standards. Installation of the ETCS system in the ordered vehicles is also possible. After completing the manufacturing process, it is required for each vehicle to cover 150 thousand kilometres over 6-12 months as part of supervised operation. The manufacturer is planning to deliver the first units in the second half of 2021. PKP IC intends to initially allocate Flirt units to run on routes in the Szczecin - Lublin - Kraków triangle, relative to such previous routes as:

- Warsaw - Bydgoszcz;

- Olsztyn - Warsaw - Kielce - Kraków;

- Gdynia - Bydgoszcz - Łódź - Katowice;

- Kraków - (on the CMK) Łódź - Kutno - Poznań Szczecin.

For the purpose of implementing the PKP IC order, Stadler decided to construct a new, $165 \mathrm{~m}$ long production hall within the Siedlce plant, at a cost of PLN $44 \mathrm{~m}$. The contract for the purchase of 12 Flirt units for PKP IC is part of a PLN 7 bn programme "PKP Intercity - Large Investment Railway", which involves rolling stock renovation. The programme has been in place for several years and covers the acquisition of Pendolino, Flirt, and Dart units to handle EIP and IC routes. It includes the modernisation of already owned EMUs of the ED74 series (contract performed by Pesa for PLN $274 \mathrm{~m}$.). The operator is also planning to purchase double-deck EMUs to handle the overburdened Warsaw - Łódź route, where the currently operated Flirt units run on double traction.

Another contract implemented by Stadler for Polish operators is one for the supply of a total of 71 units ordered in January 2018 by Koleje Mazowieckie ( 2 to 5 cars, 10 to 61 units, respectively) $[65,66]$ with a total value of PLN 2.2 bn (Fig. 18). The operator benefits from EU funding granted under the RPO WM (Regional Operational Project for the Mazowieckie Province) (subsidy of PLN $96.16 \mathrm{~m}$.) and OPI\&E 2014-2020 (subsidy of PLN 580 m.) under Measure 5.2 "Development of rail transport outside of TEN-T of the Operational Programme Infrastructure and Environment 2014-202" [14]. EU funding of a record-breaking amount of PLN $580.25 \mathrm{~m}$ was obtained. This covers $50 \%$ of the eligible expenditure amount. The new Flirt vehicles are compliant with the latest Technical Specifications for Interoperability (TSI). The entire contract has been divided into several parts that cover the purchase of 5-car EMUs with a total of 59 units:

- first part: $6 \times 5$-car vehicles running on the Łowicz - Sochaczew - Warsaw - Celestynów (Railway Line 6) routes, contract signed in May 2018, all vehicles already delivered and accepted;

- second part: $12 \times 5$-car EMUs for the Skierniewice - Warsaw - Mińsk Mazowiecki sections, contract value PLN $398 \mathrm{~m}$. gross (co-financing from OPI\&E 2014-2020 to the amount of PLN $126.05 \mathrm{~m}$.), concluded in March 2019, 6 EMUs delivered (as of mid-September 2020);

- third part: $15 \times 5$-car EMUs, for the Góra Kalwaria / Czachówek - Warsaw - Modlin lines, conclusion planned in the near future; 
- fourth part: $16 \times 5$-car EMUs, for the Warsaw Tłuszcz section, conclusion also planned in the near future;

- fifth part: $10 \times 2$-car EMUs to run on the Radom Dęblin / Skarżysko-Kamienna / Drzewica / Warka routes (Radom exit lines).

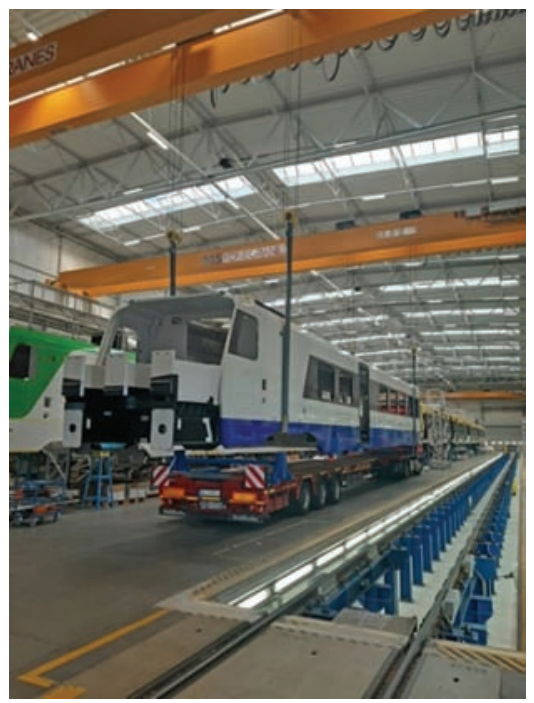

Fig. 18. Bodies of the first Flirt EMU for PKP IC, Stadler plant in Siedlce [photo M. Jarosińska / Stadler, 12.08.2020]

The manufacturer offered not only to make the contracted EMUs and train the personnel (drivers, train managers, and auditors) but also to conduct 2 P4-level maintenance repairs and provide servicing, as well as to supply a post-collision (repair) package. Initial technical acceptance was conducted at the Stadler plant in Siedlce, followed by supervised runs (without passengers) and final acceptance in June 2020 at the Rolling Stock Repair and Operation Section, Warszawa Grochów. Maintenance and repair services will be provided for the new trains. In late June 2020, a contract with Stadler Service Polska for the construction of technical facilities, valued at PLN 20 m., was concluded at the Koleje Mazowieckie premises in Sochaczów [80]. A 2,500 sq. m hall will feature 2 service tracks, technical repair spaces, workshops, a warehouse, a social and office building, as well as track, road, and parking infrastructure. The possibility to expand the facility was also provided for, and the completion date is Autumn 2021. It is planned to conduct all running repairs and P1 to P3 maintenance services at this location. The entire facility will be located within the premises of the existing Koleje Mazowieckie Rolling Stock Repair and Operation Section, on the border of the city and municipality of Sochaczew. The acceptance of new Flirt units entails the decommissioning of previously operated EN57 units (non-modernised ones in particular). Modern rolling stock is also entering more lines, to- gether with the modernised outbound lines running from Warsaw. The following lines are currently being reconstructed:

- LK (Railway Line) 8 on the Czachówek - Radom section, including the construction of a second track on the Warka - Radom section, as well as increasing the curve radii and enabling an increase in speed to $160 \mathrm{~km} / \mathrm{h}$ along the entire line (Warsaw - Radom); the line has been partially approved for use and operation as of late June 2021 [70].

- LK 7, Warsaw - Otwock - Dęblin - Lublin: Otwock - Pilawa is currently being modernised this involves the construction of a second track and increasing the speed to $160 \mathrm{~km} / \mathrm{h}$ (this modernisation was at the partially completed stage as of August 2020) [58]. The Warszawa Wschodnia - Warszawa Falenica section still remains to be modernised.

Other outbound lines from Warsaw have been upgraded and adapted to a speed of $160 \mathrm{~km} / \mathrm{h}$, although such a value is rarely achieved in the course of operating EMUs in regional traffic due to the short distances between stops. In practice, the rational travel speed is 130 $\mathrm{km} / \mathrm{h}$, as this enables the capabilities of the new rolling stock to be utilised and the travel time to be shortened, while ensuring reasonable energy consumption.

The last contract performed by Stadler for Poland's operator is one signed in April 2019, and concerns the expansion of 10 Flirt EMUs operated by Łódzka Kolej Aglomeracyjna (Łódz Agglomeration Railway) - from the current 2-car to 3-car units. The vehicles are being rebuilt in the plant in Siedlce - the first unit was completed in late July 2020 [56]. The reconstructed EMUs will undergo tests on the experimental track at the Railway Research Institute in Węglewo near Żmigród. It should be added that the Flirt units ordered by ŁKA, unlike the other 2-car Flirt units manufactured by Stadler, received two drive bogies instead of one. This was to facilitate their expansion in the future. Vehicle expansion will result in an increased number of passenger seats - from 120 to 186 , which will lead to a situation that some routes will require rolling stock to be serviced by 1 unit instead of the current double-traction service. The vehicle expansion process is conducted with financial aid from the Regional Operational Project for the Łódzkie Province.

Stadler's plant in Siedlce primarily manufactures MUs, including Flirts or GTW (Gelenktriebwagen; these MUs have a drive system located in a separate car, usually in the middle of the vehicle), and are either electric (including multi-system) or diesel driven - and supplied to the carrier market in Europe $(1,435 \mathrm{~mm}$ track gauge). A list of Stadler vehicles manufactured in the Siedlce plant in the years 2017-2020 is provided in Table 2. 
List of Stadler contracts (MUs) carried out in the years 2017-2020 in Poland in the Siedlce plant

\begin{tabular}{|c|c|c|c|c|c|c|c|c|}
\hline Operator & Country & $\begin{array}{c}\text { Vehicle } \\
\text { type }\end{array}$ & $\begin{array}{l}\text { Number } \\
\text { of units in } \\
\text { vehicle }\end{array}$ & Drive & Voltage & $\begin{array}{l}\text { Rail } \\
\text { gauge } \\
{[\mathrm{mm}]}\end{array}$ & $\begin{array}{l}\text { Number of } \\
\text { vehicles }\end{array}$ & $\begin{array}{l}\text { Production } \\
\text { period }\end{array}$ \\
\hline Arriva / Limburg & Netherlands & Flirt & 2 & electric & $1.5 \mathrm{kV} \mathrm{DC}$ & 1435 & 7 & $2016-2017$ \\
\hline $\begin{array}{l}\text { Arriva Limburg } \\
\text { 3-system }\end{array}$ & Netherlands & Flirt & 3 & electric & $\begin{array}{c}1.5 \mathrm{kV} \mathrm{DC}, \\
3 \mathrm{kV} \mathrm{DC} \\
15 \mathrm{kV} 16.7 \mathrm{~Hz}\end{array}$ & 1435 & 8 & $2017-2018$ \\
\hline Arriva Noordned & Netherlands & Wink & 2 & diesel & - & 1435 & 18 & $2018-2020$ \\
\hline SBH & Germany & Flirt $3 \mathrm{XL}$ & 3 & electric & $15 \mathrm{kV} 16.7 \mathrm{~Hz}$ & 1435 & 32 & $2020-2021$ \\
\hline BW1 & Germany & Flirt & 5 & electric & $15 \mathrm{kV} 16.7 \mathrm{~Hz}$ & 1435 & 16 & $2017-2020$ \\
\hline $\begin{array}{l}\text { NSB Torske Tog } \\
\text { Option } 4\end{array}$ & Norway & Flirt & 5 & $\begin{array}{l}\text { electric, } \\
\text { diesel }\end{array}$ & $15 \mathrm{kV} 16.7 \mathrm{~Hz}$ & 1435 & 18 & $2017-2020$ \\
\hline $\begin{array}{l}\text { NSB Torske Tog } \\
\text { Option } 5\end{array}$ & Norway & Flirt & 5 & electric & $15 \mathrm{kV} 16.7 \mathrm{~Hz}$ & 1435 & $\mathrm{n} / \mathrm{a}$ & $\mathrm{n} / \mathrm{a}$ \\
\hline PKP IC & Poland & Flirt & 8 & electric & $3 \mathrm{kV} \mathrm{DC}$ & 1435 & 12 & 2019-2023 \\
\hline $\begin{array}{l}\text { Koleje Mazow- } \\
\text { ieckie }\end{array}$ & Poland & Flirt & 5 & electric & $3 \mathrm{kV} \mathrm{DC}$ & 1435 & 61 & $2019-2023$ \\
\hline $\begin{array}{l}\text { Slovenske } \\
\text { železnice }\end{array}$ & Slovenia & Flirt & 4 & electric & $\begin{array}{c}3 \mathrm{kV} \mathrm{DC}, \\
15 \mathrm{kV} 16.7 \mathrm{~Hz}, \\
25 \mathrm{kV} 50 \mathrm{~Hz}\end{array}$ & 1435 & 11 & $2018-2021$ \\
\hline $\begin{array}{l}\text { Slovenske } \\
\text { železnice }\end{array}$ & Slovenia & Flirt & 4 & diesel & - & 1435 & 5 & $2018-2020$ \\
\hline $\begin{array}{l}\text { Slovenske } \\
\text { železnice }\end{array}$ & Slovenia & Kiss & 3 & electric & $\begin{array}{c}3 \mathrm{kV} \mathrm{DC} \\
15 \mathrm{kV} 16.7 \mathrm{~Hz} \\
25 \mathrm{kV} 50 \mathrm{~Hz}\end{array}$ & 1435 & 10 & $2018-2021$ \\
\hline $\begin{array}{l}\text { Slovenske } \\
\text { železnice }\end{array}$ & Slovenia & Flirt & 3 & diesel & - & 1435 & 16 & 2019-2022 \\
\hline $\begin{array}{l}\text { Slovenske } \\
\text { železnice }\end{array}$ & Slovenia & Flirt & 4 & electric & $\begin{array}{c}3 \mathrm{kV} \mathrm{DC}, \\
15 \mathrm{kV} 16.7 \mathrm{~Hz}, \\
25 \mathrm{kV} 50 \mathrm{~Hz}\end{array}$ & 1435 & 10 & 2019-2022 \\
\hline GySEV & Hungary & Flirt & 4 & electric & $25 \mathrm{kV} 50 \mathrm{~Hz}$ & 1435 & 10 & $2017-2018$ \\
\hline $\begin{array}{l}\text { East Anglia } \\
\text { Abelio }\end{array}$ & Great Britain & Flirt & 4 & electric & $25 \mathrm{kV} 50 \mathrm{~Hz}$ & 1435 & 21 & $2017-2019$ \\
\hline $\begin{array}{l}\text { East Anglia } \\
\text { Abelio }\end{array}$ & Great Britain & Flirt & 3 & $\begin{array}{l}\text { electric, } \\
\text { diesel }\end{array}$ & $25 \mathrm{kV} 50 \mathrm{~Hz}$ & 1435 & 14 & 2017-2019 \\
\hline EAV & Italy & Flirt & 4 & diesel & - & 1435 & 5 & $2021-2022$ \\
\hline FNM & Italy & GTW 4/12 & 4 & diesel & - & 1435 & 4 & 2016-2017 \\
\hline FNM & Italy & Flirt & 4 & diesel & - & 1435 & 30 & 2020-2024 \\
\hline TPER & Italy & Flirt & 5 & electric & $3 \mathrm{kV} \mathrm{DC}$ & 1435 & 7 & $2016-2017$ \\
\hline
\end{tabular}

[Source: M. Jarosińska / Stadler]

\subsection{Greenbrier - Wagony Świdnica}

The largest manufacturer of freight cars in Poland is the Wagony Świdnica plant, which, after acquisition and recapitalisation by the American Greenbier concern, has become the largest rolling stock exporter in Poland in terms of production volume. The access to modern technologies that has been enabled by the new owner and the large unit contracts that have been won (which enables a reduction in unit price), not only in Poland but also in several EU countries, North America, and the Middle East, are not without significance. Wagony Świdnica currently manufactures, among others, tankers for liquids (crude oil, petroleum products) and gases (propane, butane), coal wagon (coal, aggregate), flatcars, and car wagon, with $60 \%$ of the output being exported [81]. Starting in 1989 , the plant has annually produced 1 thousand cars on average (approximately 100 per month or 3 per day), while the production capacity has amounted to 
1.5-2.0 thousand per year. The plant, which has its own 50-employee engineering office, employs 1,600 people. According to the manufacturer's released business data, the order portfolio includes 27 thousand cars. Proof of its high manufacturing quality was the implementation of an order for an operator from Saudi Arabia $^{8}$ - the supply of 1,185 carriages for transporting liquid sulphur. The manufacturer has developed new bogies with a maximum axle load of $25 \mathrm{t}$, while the produced cars are made of high-strength materials, which enables e.g. reducing the size of the main frame in tankers, while simultaneously increasing the liquid tank volume. Greenbier is also the owner of an overhaul plant in Oława and a repair plant in Tarnobrzeg. The Wagony Świdnica plant assembles [23]:

- container transport flat wagons - series: Sgnss 60, Sggrss 80', Sggnss 80', Sggmrss 90', Sffggmrrss - for FLA 2 X 40, FKA 2 X 50, FEA 2 X 60, FAA 40 UK;

- tanker wagons - series: Zags $53 \mathrm{~m}^{3}$, Zacens $73 \mathrm{~m}^{3}$, Zaens $73 \mathrm{~m}^{3}$, Zacens $79 \mathrm{~m}^{3}$, Zans $85 \mathrm{~m}^{3}$, Zacns $87 \mathrm{~m}^{3}$, Zacns $95 \mathrm{~m}^{3}, \mathrm{Za}(\mathrm{c}) \mathrm{ns} 97 \mathrm{~m}^{3}, \mathrm{Za}(\mathrm{c}) \mathrm{ns} 99.5 \mathrm{~m}^{3}, 102 \mathrm{~m}^{3}$ -Z08D, Zags $102 \mathrm{~m}^{3}$, Zags $103 \mathrm{~m}^{3}$, Zags $106 \mathrm{~m}^{3}$, Zags $113 \mathrm{~m}^{3}$, Zags $116 \mathrm{~m}^{3}$, Zags $120 \mathrm{~m}^{3}$, Zags $123 \mathrm{~m}^{3}$;

- flatcars - series: Rijmmns 660, Sns-x, Rns 674, Rglns 673, Rns-z;

- coal wagons - series: JNA UK 42,9 Eamnos $57 \mathrm{~m}^{3}$ -E06A, Eamnos $57 \mathrm{~m}^{3}-\mathrm{E} 06 \mathrm{~B}$, Eamnos $72 \mathrm{~m}^{3}$ E04E, JNA $60 \mathrm{~m}^{3}$, Eanos $82.5 \mathrm{~m}^{3}$;

- covered freight wagons with sliding side walls - series: Hbbillns, Rils-y 653, Habbii(ll)ns 352, Habbiillns (Habbiins) - H01A;

- dumping wagons - series: Tanpps $55 \mathrm{~m}^{3}-\mathrm{T} 05 \mathrm{~A}$, H0a $55 \mathrm{~m}^{3}$, Falns $18477 \mathrm{~m}^{3}$, Tanos $78 \mathrm{~m}^{3}$-T03A, Tadns $82 \mathrm{~m}^{3}$, Falns $85 \mathrm{~m}^{3}$, Falns $18186.6 \mathrm{~m}^{3}$, Falns $87 \mathrm{~m}^{3}$, Tagnoos $89890 \mathrm{~m}^{3}$, IIA $90 \mathrm{~m}^{3}$, Tagnpps $95 \mathrm{~m}^{3}$ (length $14,800 \mathrm{~mm}$ and 17,170 mm), Tagnpps $102 \mathrm{~m}^{3}$, Uagnpps $105 \mathrm{~m}^{3}$, Tanoos $123 \mathrm{~m}^{3}$, Tagnpps $130 \mathrm{~m}^{3}$;

- covered wagons with foldable side walls - series: Shimmns S10B, Shimmns S10C, Shimmns ttu 724, Shimmns, Smmnps, Sfhimmns, Shmmnss;

- car carriers wagons - series: Laaers L04A, Laadrs, Laaers L02A, Laaers L07A, Laaers L08A;

- special wagons - series: Faccns (Xans), Faeeprrs (SSDT), SSDCT, for transporting railway sleepers for MRA UK;

- bogies - types: GB25RS, Y25Lsi(f)-DD1, Y25Lsi(f)-DC1, Y25Lsd-K/-K-V, Y25Lsde-K/-KV, Y25Ls(s)d1-K, Y25Ls(s)(d)i(f)1-K, Y25Lsdi(f)KB1, Y25Lsdi(f)-KC1，25Lsd-KP1，Y25Lsdi(f)KW1, 3ASL1o-K(V).
- apart from two-axle car wagons, other cars feature two 2-axle bogies each.

\subsection{Zastal Zielona Góra}

The Zastal Zielona Góra plant is a transformed entity that significantly reduced its production output after 1989 due to the collapse of the eastern (Soviet) market. Prior to 1989, the plant produced, among others, light diesel locomotives for operation on industrial sidings (the Ls60, SM03/SM04 series, 410D and $803 \mathrm{D}$ types) as well as $601 \mathrm{~W}, 408 \mathrm{~W}$, and $401 \mathrm{Wk}$ coal wagons, $1 \mathrm{R}$ tankers, $14 \mathrm{~K}$ covered wagons, and $1 \mathrm{~L}$ coolers [25]. The plant has given up on manufacturing finished freight wagons in favour of producing class 1 , 2 , and 3 steel structures, in accordance with the PN-M 69008 standard, using unalloyed or low-alloy structural steel, including in particular:

- steel structures;

- structural elements of machinery and technical devices;

- girder structures, trusses,

- industrial systems,

- tanks, containers,

- belt and chain conveyors,

- environmental protection elements,

- landings, stairs, handrails,

- installation and welding instruments,

- construction fittings.

The Zastal plant makes use of such technological processes as sand-blasting, sheet metal cutting and bending, as well as hydrodynamic coating:

- sand-blasting / shot-blasting: steel structures are cleaned in two shot-blasting booths of the internal dimensions of chambers of $5 \times 5 \times 15 \mathrm{~m}$ and $6 \times 6 \times 30 \mathrm{~m}$, equipped with abrasive material scraping and conveying machines;

- sheet metal cutting (with propane and plasma) on a table of the dimensions of $3 \times 12 \mathrm{~m}$ as well as using two innovative Mitsubishi lasers with $1.5 \times 3 \mathrm{~m}$ work tables. The cutting capacities are:

- normal - $140 \mathrm{~mm}$ (propane) - $28 \mathrm{~mm}$ (laser);

- stainless - $16 \mathrm{~mm}$ (plasma) - $12 \mathrm{~mm}$ (laser);

- aluminium - $18 \mathrm{~mm}$ (laser).

One of the lasers is equipped with an attachment for machining pipes and profiles. The capacities are:

- min. / max. diameter 15 / 240 mm;

- max. length 3,000 mm;

- max. material mass $115 \mathrm{~kg}$;

- rotational speed 33.5 RPM.

\footnotetext{
${ }^{8}$ Orders made by petroleum-producing countries from the Persian Gulf are characterised by the expectation of very high quality with regard to the supplied products, which is also appreciated in the form of high remuneration paid to the manufacturers.
} 
Materials are also cut on a hydraulic guillotine and by band-saws, with the following cutting thickness capacities:

- sheet metal - on guillotines up to $3 \mathrm{~m}$ wide and $13 \mathrm{~mm}$ thick;

- sections - on band-saws with maximum crosssections of $600 \times 400 \mathrm{~mm}$;

- bending of sheet metal, workpieces, etc.: on two hydraulic press brakes:

- Durma - maximum bending length 3,050 mm, pressing force $320 \mathrm{t}$;

- Baykal - maximum bending length 4,100 mm, pressing force $300 \mathrm{t}$;

- hydrodynamic coating: with primers and top coats.

\subsection{Europejskie Konsorcjum Kolejowe WAGON in Ostrów Wielkopolski}

The history of the Europejskie Konsorcjum Kolejowe (European Railway Consortium) WAGON in Ostrów Wielkopolski after 1989 is similar to that of Zastal Zielona Góra. Following the decline in transport in Poland resulting from the transition from the command and quota system to a free market, which led to a reduction in the volume of orders mainly from PKP, the company's management commenced restructuring. However, neither the accession to the mass privatisation programme in 1995 nor the transfer of $15 \%$ of the shares to the plant's employees a year later prevented the plant's bankruptcy in 2004. The bankruptcy trustee then sold the plant's assets to several companies, which enabled the formation of a new entity under the name of Kuźnia Ostrów Wielkopolski sp. z o.o., which manufactured metal elements for the railway (orders from, among others, PKP Cargo), shipbuilding, and machinery industries, and also provided turning, welding, and installation services related to steel structures. Since 2010, after being purchased by a new owner, the plant has been operating under the name "Europejskie Konsorcjum Kolejowe WAGON sp. z o.o.". Some of the facilities intended for office workers were not needed and were handed over to other entities from the education or healthcare sectors. The plant is a subcontractor for other railway industry enterprises, and it manufactures freight wagons and wagons bogies as well as parts, assemblies, and subassemblies for freight wagons, including those based on the ordering party's design documentation. The manufacturing portfolio offers the following freight wagons and wagons bogie series [26]:

- container flatcars - series: Sgnss-K 60', SggmrssK 80', Sggmrss-K 90', Sgns(s) 60', Sggmrss 80, Sggmrss 90', Sggmrss 104';

- coal wagons - series: Eaos, Eas, Es, Eamos, Eans, Eanos, Tamns, Eans-K, Eanos-K;
- dumping wagons - series: Fals, Falns, Tadns, Tads; - flatcars - series: Rils, Res, Snpss, Scs, Shimms, Lgs;

- pocket wagons - series: Sdgmnss, Sdggmrss;

- bogies for freight wagons of the following types: Y25 Ls(s)d1, Y25 Ls(s)1, Y25 Ls(s)d1-K, Y25 Ls(s) $1-\mathrm{K}, \mathrm{Y} 25 / 25 \mathrm{t}$.

The entity also provides services in the field of overhauls and repairs at the P2, P3, P4, and P5 maintenance levels, as well as reconstruction and modernisation of all freight wagons types, including:

- coal wagons with normal (type E) and special (type F) structures;

- flatcars on normal (types $\mathrm{R}, \mathrm{K}, \mathrm{O}$ ) and special (types S, L) bogies;

- tankers (type Z) - without tank repair and inspection;

- wagons with a retractable roof (type T);

- covered wagons with normal (type G) and special (type H) structures;

- special wagons (type U);

as well as repairs and regeneration of all parts, assemblies, and subassemblies for freight wagons, among others:

- complete bogies, bogie frames;

- wheelsets;

- full-bearing axle boxes;

- rolling stock running gear springing elements;

- draw and buffer gear;

- brake parts and air brake fittings;

- unloading mechanisms;

- external devices.

The plant also manufactures steel elements, and offers:

- design and construction of freight wagons, wagons bogies, as well as parts, assemblies, and subassemblies for freight wagons;

- development of complete technical documentation for freight wagons and wagons bogies - as required by applicable law;

- execution of freight wagons and wagons bogie prototypes;

- approval of the scope of testing required for obtaining EC Certificates with all research units;

- representation of clients in discussions with the President of ORT in matters related to obtaining Operation Approval Certificates for a railway vehicle type or a specific assembly, subassembly or element;

- representation of clients in discussion with Certification Bodies in matters associated with obtaining EC Certificates for carriages - structural subsystems and wagon bogies - interoperability constituents, pursuant to Directive 2008/57/EC (2001/16/EC) and the Commission Decision TSI WAG (freight carriages) and TSI NOI (noise). 


\subsection{Tabor Dębica}

The youngest freight carriage manufacturer in Poland is Zakłady Produkcyjno-Naprawcze Taboru Maszyn i Urządzeń “Tabor” M. Dybowski Sp. J., established in 1993 and transformed into two entities in 2013 [76]:

1) Zakłady Produkcyjno-Naprawcze Taboru Maszyn i Urządzeń “Tabor” M. Dybowski Sp. J. - rail transport;

2) Tabor Dębica Sp. z o.o. - rolling stock manufacturing and repairs.

Tabor Dębica manufactures freight wagons such as:

- $438 \mathrm{~W}$ and 438Wa coal wagons of the Eanoss series;

- $451 \mathrm{Z}$ flatcars of the Sggns series, $451 \mathrm{Za}$ of the Rbns series, $452 \mathrm{Z}$ and $453 \mathrm{Z}$ of the Res series;

- $455 \mathrm{Va}$ dumping wagons of the Fas series;

- $402 \mathrm{Rc}$ tanker wagons of the Zaces series;

- $441 \mathrm{Sa}$ cement-carrier wagons of the Uacns series;

- $455 Z c$ high-temperature material wagons.

\section{Conclusions}

Rail vehicle manufacturers in today's Poland produce locomotives and multiple units (diesel and electric) as well as underground trains for both domestic and foreign clients. Poland's domestic manufacturers usually produce single-system locomotives and multiple units, sometimes diesel-driven. In contrast, the manufacturing of more advanced vehicles - multisystem locomotives or MUs, high-speed trains, and underground trains is dominated by international manufacturers who own plants in Poland and, owing to the ability to acquire or hold larger capital, are able to freely develop new technologies (e.g. production robotisation) that are currently unavailable to domestic producers. Nevertheless, contracts are awarded to virtually all companies. Therefore, each plant is engaged in the production process. Stimuli include the possibility of receiving EU funding for rolling stock purchases as well as the numerous modernisations of PKP infrastructure financed in recent years by the National Railway Programme and still carried out, also with EU financial aid. Freight carriages are also manufactured - mainly by the plants of large producers (Greenbier from the USA) and primarily for export.

A distinctive feature of the post-1989 Polish rolling stock industry is the significantly higher quality of manufactured vehicles, and exporting ready-made units is currently a natural process. However, before 1989 , it was limited mainly to freight carriages and (to a lesser extent) passenger carriages.

\section{References}

1. Alstom completes Bombardier Transportation acquisition to create 'a global mobility leader', 29 January, 2021, Railway Gazette International.

2. Alstom completes Bombardier Transportation takeover, 29 January, 2021, International Railway Journal.

3. Alstom expects to acquire Bombardier Transportation for less than envisaged, 16 September, 2020 International Railway Journal.

4. Alstom proposes investments to obtain approval for Bombardier Transportation acquisition, 9 July 2020, International Railway Journal.

5. Alstom signs Bombardier Transportation sale and purchase agreement with revised price, 16 September 2020, Railway Gazette International.

6. Alstom to consider weak Bombardier Transportation results in takeover talks, Aug 10, 2020, International Railway Journal.

7. Alstom unveils Coradia Stream modular EMU designs for NS and Trenitalia Railway, Gazette, 3 October 2017, 2020, Railway Gazette International.

8. Alstom's acquisition of Bombardier Transportation cleared by European Commission, 31 July 2020, Railway Gazette International.

9. Alstom's sales down $27 \%$ but orders increase in first quarter results, July 16, 2020, International Railway Journal.

10. Alstom-Bombardier Transportation: concessions proposed to appease EC, July 9, 2020, International Railway Journal.

11.Czubiński R.: Newag: Bardzo dobre finansowo pierwsze pótrocze $2020 \mathrm{r}$. [A financially very good first half of 2020], Rynek Kolejowy, 10/9/2020.

12. Czubiński R:. Newag: Raport półroczny potwierdził zwiększony zysk [Semi-annual report confirmed increased profit], Rynek Kolejowy, 28/9/2020.

13.Dragon 2 dla Rail Capital Partners oficjalnie przekazany [Dragon 2 for Rail Capital Partners officially handed over], Rynek Kolejowy, 05.10.2020.

14. Dwa kolejne Flirty trafily do Kolei Mazowieckich 08.09.2020 [Two more Flirt units received by Koleje Mazowieckie], Rynek Kolejowy 8/9/2020.

15.EC approves Alstom's Bombardier Transportation acquisition, International Railway Journal, July 31, 2020.

16.ELFY.EU wjeżdżają do Czech! PESA podpisuje umowę z RegioJet [ELFY.EU enters the Czech Republic! PESA signs a contract with RegioJet], 07.03.2019, https://transinfo.pl/inforail/elfy-euwjezdzaja-do-czech-pesa-podpisuje-umowe-zregiojet-_more_112910/.

17. FPS ma miliard złotych w portfelu zamówień [FPS order portfolio is valued at a billion PLN], FPS press release, 20.03.2020. 
18. FPS zmodernisuje manewrowe lokomotywy PKP Intercity [FPS is modernising PKP Intercity's shunting locomotives], PKP Intercity press release, 02.12.2019.

19. Graff M.: Nowe elektryczne zespoly trakcyjne w obstudze ruchu regionalnego i dalekobieżnego $w$ Polsce $w 2015 r$. [New electric multiple units in regional and long-haul traffic in Poland in 2015], TTS Technika Transportu Szynowego, 9/2016.

20. Graff M.: Nowoczesne elektryczne zespoly trakcyjne $w$ Polsce [Modern electric multiple units in Poland], TTS Technika Transportu Szynowego, 5-6/2014.

21. Graff M.: Przemyst taboru szynoweg w Polsce [Rolling stock industry in Poland], TTS Technika Transportu Szynowego, 9/2017.

22. Graff M.: Rozwój systemu kolei miejskiej w Warszawie [Development of the municipal rail system in Warsaw], TTS Technika Transportu Szynowego, $1-2 / 2020$

23. Greenbrier Europe, Product catalogue. Freight wagons. Tank wagons. Car carrier. Bogies. www. greenbrier-europe.com.

24. Grupa Santander i KUKE wspierają ekspansję Pesy na białoruskim rynku [Santander Group and KUKE support PESA's expansion on the Belarusian market], 20.07.2020, https://www.kuke.com. pl/aktualnosci/grupa-santander-i-kuke-wspierajaekspansje-pesy-na-bialoruskim-rynku,143.html.

25.http://www.zastal.pl/.

26.https://ekk-wagon.pl/Oferta/tabid/57/language/ pl-PL/Default.aspx.

27.https://www.alstom.com/pl/press-releasesnews/2018/11/pierwszy-sklad-metra-dla-dubajudostarczony-terminowo-przez-alstom.

28. ICNG On Test In The Netherlands, 19 June 2020, http://www.railvolution.net/news/icng-on-testin-the-netherlands.

29. Kilanowski P.: Kłopotliwe wagony typu Bautzen 89 przewoźnika PKP IC [Troublesome Bautzen 89 carriages at PKP IC], Świat kolei, 2/2020.

30. Knorr-Bremse wins Egyptian passenger coach braking contract, International Railway Journal, 16 April, 2020.

31.ŁKA zwiększa liczbę połączeń. Impulsy w komplecie [ $€ K A$ increases the number of services. Impulse units are all here, 6/11/2019], ŁKA press release, 06.11.2019.

32. Madrjas J.: Alstom Konstal podwoił moce produkcyjne. Aluminiowy lider [Alstom Konstal doubled its production capacity. Leader in aluminium], Rynek Kolejowy, 26.11.2020.

33. Madrjas J.: FPS rozpoczął przygotowania do dopuszczenia nowych wagonów w Niemczech [FPS has started preparations for the approval of new cars in Germany, Rynek Kolejowy, 31.05.2019.
34. Madrjas J.: Największa umowa w historii Newagu podpisana. Elektronicznie [Largest contract in the history of Newag has been signed. Electronically], Rynek Kolejowy, 07.04.2020.

35. Madrjas J.: Newag podpisat umowe $z$ Kolejami Wielkopolskimi na dostawe nowych pociagów $[\mathrm{Ne}-$ wag has entered into a contract with Koleje Wielkopolskie for the supply of new trains], Rynek Kolejowy, 16.09.2019.

36. Madrjas J.: Newag zakończył dostawy 30 Griffinów dla PKP Intercity [Newag has completed the supply of 30 Griffins units for PKP Intercity], Rynek Kolejowy, 29.11.2020.

37. Madrjas J.: Pesa dostarczy lokomotywę Gama do Pol -Miedź Transu [Pesa to supply a Gama locomotive to Pol-Miedź Trans], Rynek Kolejowy, 07.07.2020.

38. Madrjas J.: Pesa dostarczyła 83 zmodernizowane wagony do PKP IC [Pesa delivered 83 modernised carriages to PKP IC], Rynek Kolejowy, 28.07.2020.

39. Madrjas J.: Pesa i PKP Cargo porozumiały sie $w$ sprawie zmniejszenia liczby napraw ST44 [Pesa and PKP Cargo agreed on a reduction in the number of ST44 repairs], Rynek Kolejowy, 07.07.2020.

40. Madrjas J:. Pesa $z$ umowa na dostawe nowych pociagów dla Małopolski [Pesa with a contract for the supply of new trains for Małopolska], Rynek Kolejowy, 28.10.2019.

41. Madrjas J.: Pesa $z$ ważna umowa $z$ RegioJet. Dostarczy pierwsze wielosystemowe Elfy [Pesa with a valid contract with RegioJet. It will deliver the first multi-system Elf units], Rynek Kolejowy, 07.03.2019.

42. Madrjas J.: Pierwszy dwusystemowy Dragon $2 z \mathrm{Ne}$ wagu pojechat na testy [First dual-system Dragon 2 from Newag in testing], Rynek Kolejowy, 14.09.2020.

43. Madrjas J.: Spalinowy Impuls dla Kolei Wielkopolskich gotowy [Diesel Impuls for Koleje Wielkopolskie is ready], Rynek Kolejowy, 29.09.2020.

44. Madrjas J.: Tak będzie wygladać hybryda Newagu dla Pomorza Zachodniego [This is how the Newag hybrid for Pomorze Zachodnie will look], Rynek Kolejowy, 16.07.2020.

45. Małopolska skorzystała z opcji. Dwa dodatkowe Impulsy [Małopolska exercised the option right. Two additional Impulses], Rynek Kolejowy, 25.09.2020.

46. Massel A.: Rozwój sieci TEN-T w Polsce [Development of the TEN-T network in Poland], Technika Transportu Szynowego, 9/2016.

47. Newag dostarczy hybrydy Kolejom Dolnośląskim [Newag to deliver hybrids to Koleje Dolnośląskie], Rynek Kolejowy, 26/8/2020.

48. Newag dostarczy na Podkarpacie Impulsy 2 i spalinowe 222Ma [Newag to deliver Impulse 2 and diesel 222Ma units to Podkarpacie], Rynek Kolejowy, 31.07.2019. 
49. Newag dostarczy osiem Impulsów dla województwa lubelskiego [Newag to deliver eight Impulses for the Lubelskie Province], Rynek Kolejowy, 09.12.2019.

50. Newag otwiera tor do testowania pojazdów wielosystemowych [Newag launches a test track for multi-system vehicles], Newag press release, 26.11.2020.

51. Newag z umową na dostawę dwóch szt-ów dla województwa lubuskiego [Newag with a contract for the supply of two DMUs for the Lubuskie Province], press release of the Marshall's Office of the Lubuskie Province, 16.11.2018.

52. Nowy etap dla Pesy: Bardziej rentowna produkcja i projekty rozwojowe [New stage for Pesa: More profitable production and development projects], 30.09.2020, http://infobus.pl/nowy-etap-dla-pesybardziej-rentowna-produkcja-i-projekty-rozwojowe_more_127507.html.

53. Pesa 760M zmienia Kolej Białoruską 19 grudnia 2019 [Pesa 760M is changing Belarusian Railways, 19 December 2019] Source: Pesa.

54. Pesa $\mathrm{z}$ kolejną umową na Elfy $2 \mathrm{w}$ Wielkopolsce [Pesa with another contract for Elf 2 units in Wielkopolska], press release of the Marshall's Office of the Wielkopolskie Province.

55.Pesa zakończyła dostawy Linków dla DB [Pesa has completed the supply of Links for DB], Rynek Kolejowy, 30.09.2020.

56. Pierwszy Flirt ŁKA rozbudowany o dodatkowy człon [First ŁKA Flirt expanded with an additional car], Rynek Kolejowy, 31.07.2020.

57. PKP Intercity odebrało z FPS komplet wagonów restauracyjnych [PKP Intercity received a set of restaurant carriages from FPS], PKP Intercity press release, 07.11.2020.

58. PKP PLK: Znów pociągiem z Otwocka do Pilawy [PKP PLK: From Otwock to Pilawa by train again], 25.08.202, 0https://www.plk-sa.pl/biuro-prasowe/informacje-prasowe/znow-pociagiem-zotwocka-do-pilawy-4812/.

59. Pomorskich Impulsów będzie dziesięć - samorząd województwa wykorzysta opcję przewidzianą w przetargu 04.10.2019 [There will be ten Impulses in Pomorskie - provincial local government to exercise the option right provided for in the tender], Rynek Kolejowy, 4/10/2019].

60. Ruszyła produkcja nowych ezt-ów dla PKP Intercity [The production of new EMUs for PKP Intercity has started], 17.09.2020, http://inforail.pl/ ruszyla-produkcja-nowych-ezt-ow-dla-pkp-intercity_more_127166.html.

61. Spalinowe Impulsy Kolei Wielkopolskich wyjechały na trasy [Diesel Impulse units of Koleje Wielkopolskie have left the station], KW press release, 14.11.2020.
62. Szymajda M.: 90 zmodernizowanych wagonów od FPS już $w$ PKP Intercity [90 modernised car from FPS already at PKP Intercity], Rynek Kolejowy, 15.01.2020.

63. Szymajda M.: Cegielski przebuduje wagony 1. klasy na restauracyjne 17.12.2018 [Cegielski to convert 1st class cars to restaurant cars], Rynek Kolejowy, 17/12/2018.

64. Szymajda M.: Dwa trójczłonowe spalinowe Impulsy 2 są już w Lubuskiem [Two three-car diesel Impulse 2 units already in Lubuskie], Rynek Kolejowy, 17.11.2020.

65. Szymajda M.: Koleje Mazowieckie i Stadler z trzecia umowa na pojazdy Flirt [Koleje Mazowieckie and Stadler with a third contract for Flirt vehicles], Rynek Kolejowy, 17.09.2020.

66. Szymajda M.: Koleje Mazowieckie odebraty pierwsze Flirty z nowego zamówienia [Koleje Mazowieckie received the first Flirt units under their new contract], Rynek Kolejowy, 24.06.2020.

67.Szymajda M.: Kolejne spalinowe zespoly trakcyjne Pesy w drodze na Białoruś i Sardynię [More Pesa diesel multiple units on their way to Belarus and Sardinia], Rynek Kolejowy, 01.06.2020.

68. Szymajda M.: Małopolska zrealizuje opcję na dwa kolejne Impulsy $z$ Newagu. Będzie ich dziewięć [Małopolska to exercise the option right for two more Impulses from Newag. There will be nine in total], Rynek Kolejowy, 25.09.2020.

69. Szymajda M.: Newag dostarczyt dwa spalinowe zespoły trakcyjne 222Ma na Podkarpacie [Newag supplied two 222Ma diesel multiple units to Podkarpacie], Rynek Kolejowy, 08.10.2020.

70. Szymajda M.: Od 28 czerwca $z$ Warszawy bezpośrednio po linii $n r 8$ do Radomia. W jakim czasie? [Line No. 8 to Radom directly from Warsaw as of 28 June. In what time?], Rynek Kolejowy, 24.06.2021.

71. Szymajda M.: Pierwsze nowe wagony dla PKP Intercity będa gotowe $w 2020$ roku [First new carriages for PKP Intercity to be ready in 2020], Rynek Kolejowy, 16.01.2020.

72. Szymajda M. Pięć nowych Impulsów 2 już na Podkarpaciu [Five new Impulse 2 units in Podkarpacie], Rynek Kolejowy, 31.10.2020.

73. Szymajda M.: Sześcioczłonowy DP6 Pesy na testach [Six-car DP6 by Pesa under testing], Rynek Kolejowy, 17.07.2019.

74. Szymajda M.: Unijne pieniadze na zakup 21 Impulsów 2 dla SKM Warszawa oficjalnie zatwierdzone [EU funds for the purchase of 21 Impulse 2 for SKM Warsaw officially confirmed], Rynek Kolejowy, 17.11.2020.

75. Szymajda M.: Wszystkie Impulsy 2 już na Podkarpaciu [All Impulse 2 units already in Podkarpacie], Rynek Kolejowy, 18.12.2020. 
76. Tabor Dębica. Train wagon catalogue https://www. tabor-debica.pl/Produkcja-wagonow.html.

77. Terczyński P.: Atlas lokomotyw [Atlas of locomotives], PKMK Poznań, 2007.

78. Terczyński P.: Atlas wagonów towarowych [Atlas of freight wagons], Kolpress Poznań, 2011.

79. Umowa na Elfy2 dla Kolei Dolnośląskich podpisana [The contract for Elf2 units for Koleje Dolnośląskie has been signed], KD press release, 29.09.2020.
80.W Sochaczewie powstanie zaplecze dla nowych Flirtów Kolei Mazowieckich [New Koleje Mazowieckie facility for Flirt trains to be constructed in Sochaczew], Rynek Kolejowy, 22.06.2020.

81. Wagony Świdnica największym eksporterem taboru w Polsce [Wagony Świdnica becomes the largest rolling stock exporter in Poland], Rynek Kolejowy, 01.02.2019.

Acknowledgements: I would like to thank Alstom, Bombardier, Siemens, Škoda and Stadler, as well as the following operators: PKP IC, KW and $Ł K A$, for their help. 